\title{
The Process of International LAW- MAKING: THE RELATIONSHIP BETWEEN THE INTERNATIONAL COURT OF JUSTICE AND THE INTERNATIONAL LAW COMMISSION ${ }^{1}$
}

\author{
Marija Đorđeska
}

\author{
The George Washington University Law \\ School, Washington, DC, USA \\ email: mdordeska@law.gwu.edu
}

ĐORĐESKA, Marija. The Process of International Law-Making: The Relationship between the International Court of Justice and the International Law Commission. International and Comparative Law Review, 2015, vol. 15, no. 1, pp. 7-57. DOI: 10.1515/iclr-2016-0027.

Abstract: Article 38, para.1, of the Statute of the International Court of Justice (ICJ) defines customary international law as evidence of general practice accepted as law, understood as State practice and opinio juris. However, by identifying certain norms as an international custom without referring to the traditional evidence of State practice and opinio juris, international courts and tribunals are contributing to the formation of customary international law. This paper presents an analysis of how the International Court of Justice contributes to the formation of customary international law by relying on the draft articles of the International Law Commission (ILC).

The International Court of Justice, in "deciding in accordance with international law", also authoritatively declares what the current international law is, while the International Law Commission, although constituted of highly qualified publicists from various States, is drafting only non-binding international instruments. By relying on the ILC draft articles and declaring them to be reflecting customary international law-although the draft articles may not be necessary the expression of the States' practice and their opinio juris, the ICJ creates and generates the creation of customary international law. Interestingly, the ICJ tends to rely mostly on ILC draft articles that refer to the jurisprudence of either the Permanent Court of International Justice ("PCIJ") or the ICJ itself. The paper presents research of approximately 70 ICJ decisions and individual opinions that cite to the work of the ILC. The author notes the evolution of the relationship

1 Marija Đorđeska, LL.M., is a Science of Juridical Doctorate (S.J.D.) Candidate at The George Washington University Law School, Washington, DC. This article is an abridged version of the author's Masters of Law thesis, written in the scope of the International and Comparative Law Masters of Law (LL.M.) Program at The George Washington University Law School in 2013; e-mail: mdordeska@law.gwu.edu.

The author would like to thank her mentor, Professor Thomas Buergenthal, and Professors Sean D. Murphy, Ernest Petrič, Karen Da Ponte Thornton, Richard J. Pierce, Jr., and Mr. Kenneth Rodriguez for their insightful comments. 
between the ICJ and the ILC through three different time periods, and presents the findings on how, when and why the ICJ relies on the ILC draft articles. In addition, the author gives examples in which the ICJ rejected the reliance on the ILC's work, mainly due to the divergent interpretation on the specific area of international law.

The ICJ, by relying on the ILC draft articles that in turn refer to the jurisprudence of the ICJ or PCIJ, is not only generating norms of customary international law, but is also re-affirming the importance of its (and PCIJ's) jurisprudence for the future of international law. Although ICJ decisions are binding only between the parties to the dispute (Art.59 ICJ Statute), the clarification of whether a norm is customary or not, affects the international community of States.

Noting the present reluctance of States to adopt treaties, and- hence their potentially decreasing role in international law-making, this research offers an insight into an alternative venue of international law-making. As the international community, and the ILC itself, is regaining interest in the sources of international law, this paper aims to identify the mechanisms of international law-making, the understanding of which will contribute to international law's needed predictability and a more uniform and reliable interpretation of international law.

Keywords: International Court of Justice, International Law Commission, international law-making, judicial law-making, customary international law, Draft articles, relationship between the International Court of Justice and the International Law Commission

\section{Introduction}

The International Court of Justice ("ICJ", or "the Court")—the principal judicial organ of the United Nations-was designed to resolve disputes between States by applying existing international law, and to, also, progressive develop international law. ${ }^{2}$ The combination of finding existing international law and progressively developing international law results in international judicial lawmaking. In a system without an international legislator, in which international courts and tribunals, alongside the States, develop international law chaotically across many fields of international law" [t] he situation [of international lawmaking] resemble[s] an exploded constellation, composed of one star and the occasional rare meteor in an otherwise vast and empty universe," as Professor Georges Abi-Saab remarked. ${ }^{3}$

International law as we know it today is a consequence of decades of evolution, specialization and expansion of already known but and new fields of legal

2 G.A. Res. 171 (II) at 103, U.N. Doc. A/459 and Corr.1 (Nov. 14, 1947).

3 Georges Abi-Saab, Fragmentation or Unification: Some Concluding Remarks, 31 Int'l L. \& Pol. 919 (1999), at 924 and 931. See also Jennings, The Progress of International Law, British Y.B. Int'l L. at 46, 1958 (1959), at 343; Lassa Francis Lawrence Oppenheim, The Future of International Law, 8 Carnegie Endowment for International Peace Pamphlet Series 39, 26 (2000), at 23 (noting that have more legislative power in international law than individuals have in democratic domestic systems). 
regulation, in which international courts and tribunals played a major role. ${ }^{4}$ The ICJ, as primus inter partes, has contributed fundamentally to the development and advancement of international law. ${ }^{5}$

In this international law-making process, when the Court either clarifies existing international law or progressively develops international law, the work of the International Law Commission ("ILC") aids the Court's decision. ${ }^{6}$ The ICJ does not always refer to the evidence that leads the Court to conclude that a norm is a norm of (customary) international law. In those instances, the Court usually relies on ILC draft articles or the commentaries to the draft articles in determining State practice and/or States' opinio juris. ${ }^{7}$ The ICJ also relies on ILC

4 Stephen M. Schwebel, The Contribution of the International Court of Justice to the Development of International Law, in International Law and the Hague's 750th Anniversary 409 (Wybo P. Heere ed., 1999), at 405 and 408. Abi-Saab, Id., at 921, 923-26 and 931 (referring to the Roman maxim cuius regio, eius religio); Oppenheim, Id., at 3; Gilbert Guillaume, The Future of International Judicial Institutions, 44 Int'l \& Comp. L. Q. 848, 851 (1995), at 848; Bedi, The development of Human rights law by the Judges of the International Court of Justice, at 15 and 17 (noting terms attributed to judicial legislation, e.g. judicial legislation, judicial law-making, judge made law, development of law by judges, the creative role of the judges, judicial creativity, judicial activism, and formulating the term 'judgislation').

5 Reservations to the Convention on the Prevention and Punishment of the Crime of Genocide, Advisory Opinion, 1951 I.C.J. 15, 50 (May, 28) (dissenting opinion of Judge Alvarez); Application of the Interim Accord of 13 September 1995 (Maced. v. Greece), Judgment, 2011 I.C.J. 644, 711 (Dec. 5) (declaration of Judge Bennouna). Pemmaraju Sreenivasa Rao, Multiple International Judicial Forums: A Reflection of the Growing Strength of International Law or its Fragmentation, 25 Mich. J. Int'l L., (2003-2004), at 939, 944-945 and 959-961; Malcom N. Shaw, The International Court of Justice: A Practical Perspective, 46 Int'l \& Comp. L. Q. 831 (1997), at 839, 842 and 844; Abi-Saab, supra note 2, at 931-33; Schwebel, supra note 3, at 406, 407 and 415-16; Jennings, supra note 2, at 344; Sir Michael Wood, Introductory Remarks at the 64th Session of the International Law Commission, Formation and Evidence of Customary International Law (July 24, 2012) (acknowledging the leading role of the ICJ among other international courts and tribunals).

6 Statute of the International Court of Justice, Oct. 24, 1945, 1491 U.N.T.S. 199, art.38, para.1. E.g. "[T]he Court followed Article 8 of the International Law Commission Articles on State Responsibility." Application of the Convention on the Prevention and Punishment of the Crime of Genocide (Bosn. \& Herz. v. Serb. \& Montenegro), Judgment, 2007 I.C.J. 43, 36 (Feb. 26) (dissenting opinion of Judge Al-Khasawneh), referring to the Judgment, g9402-407 (emphasis added).

7 North Sea Continental Shelf (Fed. Rep. Germ./Neth.), Judgment, 1969 I.C.J. 3, g948, 74 (Feb. 20); proceedings joined with North Sea Continental Shelf (Fed. Rep.Germ./Denm.) (April 26, 1968); Id., at 187 (dissenting opinion of Judge Tanaka) (noting the ICJ does not conduct an extensive research). See also Rao, supra note 4, at 940; Summary Records of the 2775th Meeting, [2003] Y.B. Int'l L. Comm'n 163, U.N.Doc. A/CN.4/SR.2775. Cf. Application of the Genocide Convention Case, at 371 (declaration of Judge Skotnikov). "[I]t will be sufficient to look to the considered views expressed by States and bodies like the International Law Commission as to whether a rule of customary law exists and what its content is, or at least to use rules that are clearly formulated in a written expression as a focal point to frame and guide an inquiry into the material elements of custom." Peter Tomka, Custom and the International Court of Justice; in The Law and Practice of International Courts and 
draft articles when the ILC did not cite to State practice in drafting the draft article. In relying on such draft articles, and declaring them to be reflective of customary international law, the ICJ contributes to the progressive development of the international law. Despite the consistent consideration by the ICJ of the ILC's work, the relationship between these two international bodies has not been researched in detail. ${ }^{8}$

The most interesting aspect of this peculiar relationship is the circular reference, when the ICJ refers in its decisions to ILC's work that cites the jurisprudence of the ICJ or Permanent Court of International Justice ("PCIJ"), and does not refer to State practice or opinio juris in identifying customary norms. For example, in Gabčikovo-Nagymaros Project the Court referred to art.12 of the Vienna Convention on State Succession in Respect to Treaties, drafted by the ILC, and affirmed art.12 as part of customary international law. The ILC admitted that draft art.12 was progressively developed, which explained the lack of reference to State practice, and perhaps also the low number of States that signed the convention. Therefore, the ICJ finding that art.12 is customary international law, may be owed to the ILC's reliance on the ICJ/PCIJ jurisprudence in the commentary to art.12. ${ }^{9}$

This paper analyzes the Court's reliance on the work of the ILC. Part II compares the Court's international law-making authority in comparison to the function of the ILC. Part III categorizes the development of the ICJ-ILC relationship over time within at least three periods. Part VI analyses the ICJ-ILC relationship through time, Part V outlines the analysis of the interaction between ICJ and the ILC and how their relationship contributes to the creation of international law. The research is based on the analysis of seventy judgments, advisory opinions and Judges' individual opinions in which the author found references to ILC's work. ${ }^{10}$ Part VI highlights the disagreements in interpreting international

Tribunals (CAHDI, 2013).

8 The mutual influence between the ICJ and the ILC has already been noted. See Stephen M. Schwebel, The Inter-Active Influence of the International Court of Justice and the International Law Commission, in Justice in International Law: Further Selected Writings (2011); Hugh Thirlway, The Proliferation of International Judicial Organs and the Formation of International Law, in International Law and the Hague's 750th Anniversary (Wybo P. Heere ed., 1999), at 440; and Daniel Bethlehem, The Secret Life of International Law, 1 Cambridge J. Int'l \& Comp. L. 23, 36 (2012).

9 This conclusion is reaffirmed by the fact that in finding the customary status of the rule, the ICJ relied solely on the 1974 ILC Commentary that confirmed the ICJ's case-law, but did not refer to any state practice. Gabčikovo-Nagymaros Project (Hung./Slovk.), Judgment, 1997 I.C.J. 7, 123 (Sept. 25).

10 After surveying the jurisprudence of the Court containing a reference to the work of the ILC, the author subdivided ILC's work according to its weight in international law (draft articles, treaties in force and treaties not yet in force) and according to the topic the ILC has considered. The results showed that the Court does not differentiate substantially between a treaty provision and a draft article when it declares them to be customary international law. The division of the ILC's work into different areas of law showed that the ICJ consid- 
law offers suggestions how the cooperation between the two international bodies could be improved in the future. Although the influence between the ICJ and the ILC works in both directions, this paper is limited to the analysis of the reference by the ICJ to ILC's work, for the authority of the ICJ decisions bears a greater weight in international law. ${ }^{11}$

Despite the ICJ's increased reliance on ILC's work, there is an emerging trend of ICJ disagreeing with the ILC's interpretation of international law and its identification of norms of customary international law. When disagreeing with the ILC's work, the ICJ can modify the conclusions codified by the ILC. ${ }^{12}$ Without

ered the ILC work mostly in the areas of law of the sea and State responsibility. The ICJ avoided considering ILC's work in the areas like diplomatic protection and international environmental law. Major guidance in the research were the annual speeches of Presidents of the Court to the ILC and the scholarly article by Judge Schwebel. See Schwebel, supra note 7.

$11 I d$., at 66. ICJ influences in a great extent ILC's work, seen from the frequency of the ILC's reliance on the ICJ's decisions in drafting. "[The ICJ] undoubtedly helped solidify the views developed on various topics in the International Law Commission." Press Release, I.C.J., Statement by H.E. Judge Peter Tomka, President of the International Court of Justice, The Hague International City of Peace and Justice (May 16, 2013). Although individual opinions do not have the law-making power per se, as compared to the decisions of the Court as a whole, the author considered individual opinions due to their valuable insight into the Court's deliberations; indicate when the ICJ relies on the ILC; and because they might generate a limited secondary effect of international law-making. Individual opinions can merely influence the creation of international law; individual opinions could be compared with the work of the publicists. See e.g. Case Concerning the Appeal Relating to the Jurisdiction of the ICAO Council (India v. Pak.), Judgment, 1972 I.C.J. 46, 116 (Aug. 18) (separate opinion Judge De Castro); Request for Interpretation of the Judgment of 31 March 2004 in the Case concerning Avena and Other Mexican Nationals (Mex. v. U.S.), Judgment, 2009 I.C.J. 3, 996-64 (Jan. 19) (separate opinion of Judge ad hoc Sepulveda); Sir Hersch Lauterpacht, The Development of International Law by the International Court 65, 368-372 (Stevens \& Sons Limited, 1958), at 62 and 66; Gleider I. Hernandez, Impartiality and Bias at the International Court of Justice, 1 Cambridge J. Int'l \& Comp. L. 183, 189 (2012); Michael Peil, Scholarly Writings as a Source of Law: A Survey of the Use of Doctrine by the International Court of Justice, 1 Cambridge J. Int'l \& Comp. L. 136 (2012), at 157; Int'l L. Comm'n, Draft articles on Responsibility of States for Internationally Wrongful Acts with Commentaries, Rep. of the Int'l L. Comm'n (2001), reprinted in [2001] 2 Y.B. Int'l L. Comm'n, U.N.Doc. A/56/10 \& Corr.1. Unlike the ILC's Special Rapporteurs, judges are not bound by the acceptance of the Court as a whole of their individual position. Excluded from the scope of the research was the analysis of the interaction between the predecessors of both institutions, namely the Permanent Court of International Justice and its reference to the Vienna Congress 1815 and the Hague codification conferences in 1899, 1907, and 1930. References made by other international courts and tribunals to ILC's work were excluded from consideration.

12 Maritime Delimitation in the Area between Greenland and Jan Mayen (Den. v. Nor.), Judgment, 1993 I.C.J. 38, 9 172, 195 (June 14) (separate opinion of Judge Weeramantry) (agreeing with the development of the rule as ILC has proposed it in connection to special circumstances). Cf. Id., 18 (dissenting opinion of Judge Fischer); Eduardo Jimenez de Arechaga, The Work and the Jurisprudence of the International Court of Justice, 1947-1986, 
this freedom of judicial interpretation, international law would remain 'petrified' and would lack the ability to change as different norms ripen into custom. ${ }^{13}$

\section{International Law-Making: The Court as the Legislator and the ILC as the Observer}

International law-making as described in this work is a process of transplanting or elevating internationally non-binding legal instruments into the sphere of binding international law. ${ }^{14}$ The development of international law should mainly reflect States' action; however, the Court relies on rules that might not be reflective of the current State practice or the opinio juris. ${ }^{15}$ In deciding a dispute the Court finds and relies on rules of international law that were not known or codified prior to the dispute. ${ }^{16}$

British Y.B. Int'l L. 1, at 34-35 (1987), at 32-33. See also Armin von Bogdandy \& Ingo Venzke, On the Functions of International Courts: An Appraisal in Light of Their Burgeoning Public Authority, 26 Leiden J. Int'l L. 49 (2013), at 50, 54, 56, 72; Alina Kaczotowska, Public international Law (Routledge, 4th ed., 2010), at 15.

13 "[L]ater developments in customary international law need to be taken into account in applying the provisions of the 1958 [Geneva] Convention." Maritime Delimitation in the Area between Greenland and Jan Mayen (Den. v. Nor.), Judgment, 1993 I.C.J. 38, 134 (June 14) (individual opinion of Judge Shahabuddeen) (referring to the Anglo-French Arbitration (1977) and Delimitation of the Maritime Boundary in the Gulf of Maine Area (Can./U.S.), Judgment, 1984 I.C.J. 246, 83 (Jan. 20).

14 Oppenheim, supra note 2, at 23; Jennings, supra note 2, at 343; Felice Morgenstern, International Legislation at the Crossroads, British Y.B. Int'l L. 101, at 101-102 (1979); Bogdandy \& Venzke, supra note 11, at 55, 56. Distinction between 'making' international law and 'developing' international law is vague. See e.g. North Sea Continental Shelf (Fed. Rep. Germ./Neth.), Judgment, 1969 I.C.J. 3, 699 (Feb. 20). 'Making' international law could mean the final step of the norm transitioning into international law, unlike the development of international law that encompasses all stages of norm-creating, namely, progressive development (lacunaes), development (non-liquet) and pre-existing or emerging rule of customary law (in status nasciendi). Schwebel, supra note 3, at 407 and 412. The distinction between 'making' and 'developing' international law by the Court could be also interpreted in the sense that the ICJ 'develops' already existing international law, and 'makes' law when declares a rule not previously part of international law, to be customary international law (i.e. lacunaes, non-liquet).

15 Questions Relating to the Obligation to Prosecute or Extradite (Belg. v. Sen.), Judgment, 2012 I.C.J. 422, 9932-35 (July 20) (separate opinion of Judge Abraham). Mohamed Shahabuddeen, The Precedent in the World Court (Cambridge University Press, 1996), at 71; see also B. G. Rachmaran, The International Law Commission: Its Approach to the Codification and Progressive Development of International Law 15 (Martinus Nijhoff, 1977), at 203. The ICJ has the power to bind at least two State parties in dispute before the Court and its decisions are highly authoritative. The Statute of the International Court of Justice, A Commentary (Zimmermann, Oellers-Frahm, Tomuschat \& Tams eds., 2nd ed. (2012), at 1444-1446 (Comment to art. 59 of the ICJ Statute). Oppenheim's International Law, Volume 1, Peace (Sir Robert Jennings \& Sir Arthur Watts, eds. 9th ed. 1995), at 41.

16 Statute of the International Court of Justice, art. 59, Oct. 24, 1945, 1491 U.N.T.S. 199; Art. 38 , para.1. 
The Court's international law-making function is neither formal nor regulated, but is the result of the judicial determination of what the applicable international law is, or was at the time of the dispute. The decision of the Court, although not necessarily binding on States that are not parties to the dispute, generates State practice and further develops international law. ${ }^{17}$

The ILC, on the other hand, although exercising its mandate of codifying and progressively developing international law, does not have the ability to issue internationally binding instruments. ${ }^{18}$ The ILC draft articles do not form a part of international law until adopted by States in an international treaty, or when they form part of the consistent and widely-adopted State practice. ${ }^{19}$ The draft

17 Shaw, supra note 4, at 833, 847 and 853; see also Jimenez de Arechaga, supra note 11; Guillaume, supra note 3, at 852 (noting that the international community, but debating what the substance of international law, should place additional trust in international judges); Schwebel, supra note 3, at 406, 408 (arguing the ICJ with its authoritative and persuasive case-law contributed in shaping the law of the sea, especially by identifying emerging rules arising from the State practice); see also Shahabuddeen, supra note 14, at 68.

18 Morgenstern, supra note 13, at 105. The ILC does not make law, it only suggests what it considers to be international law, or what should become international law. The Codification Division, overseeing the ILC, "encourages' and 'promotes' progressive development of international law and its codification." United Nations Office of Legal Affairs, Codification division, http://untreaty.un.org/ola/div_cod.aspx (accessed June 23, 2013). See also Statute of the International Law Commission, art. 1. The ILC's 'quasi'-legislative power is still debated. ILC Statute does not confer to the ILC a law-making mandate for producing binding norms of international law. The ILC is producing legal documents of already existing norms or norms the ILC would develop or fill in the non-liquet in international law. The form of ILC's work is not relevant as long as States can adopt it in a treaty form. See Jennings, supra note 2, at 339; Summary Records of the 2503rd Meeting, [1997] Y.B. Int'l L. Comm'n 207, U.N.Doc. A/CN.4/SR.2503; cf. North Sea Continental Shelf (Fed. Rep. Germ./Neth.), Judgment, 1969 I.C.J. 3, 232 (Feb. 20) (individual opinion of Judge Lachs). Some scholars equate codifying international law with the authority to declare a rule to be customary international law. The reading of the ILC Statute suggests codification of international law is only a methodological approach to drafting. See Alain Pellet, Responding to New Needs Through Codification and Progressive Development (Keynote address), in Multilateral Treaty-Making: The Current Status of Challenges to and Reforms Needed in International Legislative Process (Vera Gowlland-Debass ed., 2000), at 16-18 (noting the task of the ILC is to ascertain State practice and deduce existing trends, although this is not always the case), and Provisional Summary Records of the 3159th Meeting, [2013] Y.B Int'l L. Comm'n, U.N.Doc. A/CN.4/SR.3159. The ILC does not clearly distinguish between lex lata and de lege ferendae provisions. Provisional Summary Records of the 2933rd Meeting, [2007] Y.B. Int'l L. Comm'n, U.N.Doc. A/CN.4/SR.2933; Int'l L. Comm'n, Draft articles on Diplomatic Protection with Commentaries, Rep. of the Int'l L. Comm'n (2006), reprinted in [2006] 2 Y.B. Int'l L. Comm'n, U.N.Doc. A/61/10, draft art.11, para. (b). First Rep. on the Law of Treaties (1962), at 73 et seqq. (noting the ILC predecessors at the Committee of the League of Nations in 1927 did not have the authority of establishing law). Cf. Reservations to the Convention on the Prevention and Punishment of the Crime of Genocide, Advisory Opinion, 1951 I.C.J. 15, at 35 (May, 28) (dissenting opinion of Judges Guerrero, Sir Arnold McNair, Read, Hsu Mo).

19 Vienna Convention on the Law of Treaties, art.31, para.3(c), May 23, 1969, 1155 U.N.T.S. 
articles are considered by the Court as a clarification of some legal issues, as evidence of international law, or merely as „the teachings of most highly qualified publicists of various nations" within the meaning of art.38, para.1(d) of the ICJ Statute. Despite its non-binding character, ICJ relies on ILC's work in determining the applicable law, usually resulting in international law-making. ${ }^{20}$ Both States and the Court act as an international legislator in 'elevating' ILC's work into the sphere of international law.

The ICJ develops existing international law when it declares that a norm, not previously part of customary international law, has attained the status of customary international law. ${ }^{21}$ The Court develops, 'clarifies' or 'fills the gap' in international law either by relying on the ILC draft articles or on its Commentaries. ${ }^{22}$ The Court in finding the applicable international law for the solution of

331.

20 Huang Huikang, The Commission's Work and the Shaping of International Law, (Presentation), Making Better international Law: The International Law Commission at 50, Proceedings of the United Nations Colloquium on Progressive Development and Codification of International Law (United Nations Publication, 1998), at 122. Summary Records of the 2503rd Meeting, [1997] Y.B. Int'l L. Comm'n 207, U.N.Doc. A/CN.4/SR.2503.

21 The ICJ could also rely on ILC draft article as a general principle of law. See e.g. Pulp Mills on the River Uruguay (Arg. v. Uru.), Judgment, 2010 I.C.J. 14, at 67, 145 (Apr. 20), and infra note 34. By deciding on the customary status of the rules, the Court 'codifies' the nonwritten customary rules. The Court partially takes over the task Art.13, para.1 of the UN Charter confers to the General Assembly to progressively develop and codify international law. U.N. Charter, June 6, 1945, art.13, para.1.

$22 C f$. Fisheries Jurisdiction (U.K. v. Ice.), Judgment, 1974, I.C.J. 3, 53 (July 25) (noting that the Court cannot fill the gap in the international treaty if the States wanted to do it in the future conferences). The Court in Gabčikovo-Nagymaros Project dealt with the interpretation of the notion of 'state of necessity' to determine when the resort to countermeasures is lawful. The Court relied on the Commentary to draft art.33 on State responsibility and used the ILC definition of 'state of necessity', and found that the ILC criteria reflected customary international law. By relying extensively on the findings of the ILC, the Court 'elevated' the provision contained in draft art.33 into international law and gave the previous norm also contained in draft art.33 on State responsibility, which was of pre-customary or customary nature, the content as found by the ILC. The Court considered the ILC work on 'state of necessity' in Gabčikovo-Nagymaros Case in 1997 but omitted to mention it in the 2010 Pulp Mills on the River Uruguay Case. See Gabčikovo-Nagymaros Project (Hung./Slovk.), Judgment, 1997 I.C.J. 7, 9949, 50, 52, 53 (Sept. 25); Summary Records of the 2775th Meeting, [2003] Y.B. Int'l L. Comm'n 163, U.N.Doc. A/CN.4/SR.2775; Int'1 L. Comm'n, Draft articles on Responsibility of States for Internationally Wrongful Acts with Commentaries, Rep. of the Int'1 L. Comm'n (2001); Stephen M. Schwebel, The Influence of the International Court of Justice on the Work of the International Law Commission and the Influence of the Commission on the Work of the Court (Keynote Address), Making Better international Law: The International Law Commission at 50, Proceedings of the United Nations Colloquium on Progressive Development and Codification of International Law (United Nations Publication, 1998), at 163-164. Cf. Jurisdictional Immunities of the State (Germ. v. It.: Greece intervening), Judgment, 2012 I.C.J. 99, 137 (Feb. 3) (noting the ILC draft art.30, para.(a) and art.35 on State responsibility are reflective of customary international law); see also 
a dispute between States sometimes relies on findings of the ILC and declares ILC draft articles to form part of customary international law. ${ }^{23}$ By relying on the ILC's work, the ICJ either 'elevates' or 'transplants' ILC draft articles into the sphere of customary international law. ${ }^{24}$ By declaring an internationally nonbinding rule to reflect an internationally binding customary norm for all States, the Court is impliedly ratifying ILC's work by "[accelerating] the incorporation of the work product of the Commission into the body of customary international law." 25

'Elevation' is the process of direct incorporation of non-binding ILC instruments into international (binding) law. ICJ's second international law-making process, 'transplantation', is the process of incorporation of already existing treaty provisions (drafted by the ILC and adopted by States) into customary international law. ${ }^{26}$ The Court's declaration that a rule is customary gives the

Land and Maritime Boundary between Cameroon and Nigeria (Cameroon v. Nigeria: Eq. Guinea intervening), Judgment, 2002 I.C.J. 303, 265 (Oct. 10) (relying on the ILC Commentary to the art.7, para.2 of the Vienna Convention on the Law of Treaties in determining that the Head of State has a representative function in regards to the conclusion of a treaty).

23 The Court finds that the ILC work 'reflects' customary international law or that the lacunaes or non-liquet in international law could be 'filled' with the work of the ILC. Pellet, supra note 17, at 15-16 (noting the international law-making is ars juris and there is more than one approach to how the ICJ cites the ILC and how the Court makes international law).

24 The President of the ICJ noted that the Court "reinforce[s] the value of the draft articles by declaring some principles contained therein as being of a customary nature," and impliedly ratifies the ILC's formulation of certain provisions. Summary Records of the 2775th Meeting, [2003] Y.B. Int'l L. Comm'n 163, U.N.Doc. A/CN.4/SR.2775; Summary Records of the 2585th Meeting, [1999] Y.B. Int'l L. Comm'n 122, U.N.Doc. A/CN.4/SR.2585. See also Ahmadou Sadio Diallo (Guinea v. Dem.Rep.Congo), Preliminary Objections, 2007 I.C.J. 582, 647 (May 24) (separate opinion of Judge ad hoc Mampuya); Stephen Vasciannie, The Role of the United Nations International Law Commission: A View from the Caribbean, 35 W. Indian L. J. 63 (2010), at 63.

25 Summary Records of the 2585th Meeting, [1999] Y.B. Int'l L. Comm'n 122, U.N.Doc. A/ CN.4/SR.2585, at 124; Provisional Summary Records of the 2933rd Meeting, [2007] Y.B. Int'l L. Comm'n, U.N.Doc. A/CN.4/SR.2933 (comment by Judge Xue noting the ICJ elevates the ILC work into a source of international law). See also Grigory Tunkin, Is General International Law Customary Law Only?, 4 E. J. Int'l L. 534, 539 (1993); Shaw, supra note 4, at 831 and 838. Only States persistent objectors might be exempted from the effect of the ICJ's declaration on the customary international law. ILC draft articles reflect customary international law also before the pronouncement of the Court. However, until the Court confirms the status of a rule in international law, it is not clear to the States what is the rule governing a specific area of international law. See Lauterpacht, supra note 10, at 198 and 368-372. With Court's 'clarification', these customary rules came 'into force' for other States not parties to a specific treaty. Cf. Schwebel, supra note 7, at 66.

26 Legal Consequences for States of the Continued Presence of South Africa in Namibia (South West Africa) notwithstanding Security Council Resolution 276, Advisory Opinion, 1971 I.C.J. 16, $9994-95$ (June 21). In Fisheries Jurisdiction Case the Court invoked art.52 and art.62 of VCLT and declared them to be customary international law despite the VCLT 
specific provision an existence independent of the treaty. Parallel existence of the customary and treaty rules was, for example, noted in United States Diplomatic and Consular Staff in Tehran Case. ${ }^{27}$ 'Transplantation' represents an indirect form of international law-making --the direct link between ICJ and the ILC is interrupted when States are given the opportunity to modify the draft articles when adopting a treaty. 'Transplantation' differs from 'elevation' because it only transplants the ILC draft articles from one source (i.e. international treaty law) to another one (i.e. customary international law). ${ }^{28}$

However, the Court did not always declare an ILC-drafted treaty provision to be customary international law. ${ }^{29}$ ICJ categorized ILC draft articles also as general principles of law, or, when the Court disagreed with conclusions of the Commission, it usually omitted any reference to the ILC in its decision altogether. ${ }^{30}$

not being yet in force. Also, in the Legal Consequences for States of the Continued Presence of South Africa in Namibia advisory opinion the Court relied on a provision of VLCT not yet in force and declared it to be part of customary international law. Fisheries Jurisdiction (U.K. v. Ice.), Judgment, 1974 I.C.J. 3, 59, 63 (July 25). Legal Consequences for States of the Continued Presence of South Africa in Namibia (South West Africa) notwithstanding Security Council Resolution 276, Advisory Opinion, 1971 I.C.J. 16, 994 (June 21); Rachmaran, supra note 14, at 16, 95 (noting the Court relied on VLCT when it was not yet in force), also Arechaga, supra note 11, at 33-38 (arguing art. 60 VCLT was a pre-existing customary norm when the Court relied on it in its decision); and G. M. Danilenko, LawMaking in the International Community (Martinus Njihoff, 1993), at 135, fn.17.

27 The Court opted to use the 'parallel' customary rules of the VCDR and the VCCR, despite the fact that both Iran and the United States were parties to both conventions. The Court decided that the provisions relevant to the case at hand formed part of general international law. United States Diplomatic and Consular Staff in Tehran (U.S. v. Iran), Judgment, 1980 I.C.J. 3, 62 (May 24). See also Huikang, supra note 19, at 122.

28 Also the statements the States made during the codification conference constitute part of the legislative history of the instrument. Maritime Delimitation in the Area between Greenland and Jan Mayen (Den. v. Nor.), Judgment, 1993 I.C.J. 38, 87 (June 14) (separate opinion of Judge Ranjeva).

29 For example, in Jurisdictional Immunities of the State the Court did not state what status art.19 of the United Nations Convention on Jurisdictional Immunities of States and Their Property has in international law. Jurisdictional Immunities of the State (Germ. v. It.: Greece intervening), Judgment, 2012 I.C.J. 99, g9115, 117 (Feb. 3). Another international law-making option is finding a customary rule that has superseded a treaty rule, either due to new State practice or as a consequence of a different treaty interpretation. Maritime Delimitation in the Area between Greenland and Jan Mayen (Den. v. Nor.), Judgment, 1993 I.C.J. 38, 216 (June 14) (separate opinion of Judge Shahabuddeen).

30 In Gabčikovo-Nagymaros Project, Pulp Mills on the River Uruguay Case, and in the Jurisdictional Immunities of the State Case, the Court found draft articles on State responsibility and some provisions of the Convention on the Law of the Non-Navigational Uses of International Watercourses to constitute general principles of international law in accordance with the art. 38, para.1(c) of the ICJ Statute. See Gabčikovo-Nagymaros Project (Hung./ Slovk.), Judgment, 1997 I.C.J. 7, g 141, 147 (Sept. 25); Pulp Mills on the River Uruguay (Arg. v. Uru.), Judgment, 2010 I.C.J. 14, 9964, 145, 225 (Apr. 20); Jurisdictional Immunities of the State (Germ. v. It.: Greece intervening), Judgment, 2012 I.C.J. 99, 58 (Feb. 3). The Court, however, did not refer to any legislative history in determining the meaning of these 


\section{The Court clarifies, crystalizes and develops international law}

The task of the Court is to interpret international law and, while doing so, to indicate any new emerging trends. ${ }^{31}$ The Court uses ILC's work when it 'clarifies' or 'crystallizes' international law, as the chart below shows:

\begin{tabular}{|c|c|c|}
\hline $\begin{array}{l}\text { ICJ's legisla- } \\
\text { tive-making } \\
\text { function }\end{array}$ & $\begin{array}{l}\text { Nature of the ILC pro- } \\
\text { visions the ICJ uses }\end{array}$ & $\begin{array}{l}\text { Nature of provisions the ICJ finds } \\
\text { without relying on the ILC }\end{array}$ \\
\hline Clarification & $\begin{array}{l}\text { customary interna- } \\
\text { tional law (lex lata) }\end{array}$ & customary international law (lex lata) \\
\hline Crystallization & $\begin{array}{l}\text { pre-customary } \\
\text { norms (lex lata) }\end{array}$ & pre-customary norms (lex lata) \\
\hline Development & l & $\begin{array}{l}\text { development (norms in sta- } \\
\text { tus nasciendi) (lex ferendae) }\end{array}$ \\
\hline $\begin{array}{l}\text { Progressive } \\
\text { development' }\end{array}$ & l & progressive development (lex ferendae) \\
\hline
\end{tabular}

The Court records the evolution of a rule from a lex ferendae to lex lata status in international law. Such "record" is visible in the Court's consideration of the evolving nature of art.31 Vienna Convention on the Law of Treaties (VCLT). Adopted in 1969, art.31 VCLT was considered to be lex ferendae at the time of the adoption, but the subsequent world-wide adoption of the VCLT turned this provision into a lex lata provision and a rule of customary international law over a 23 year period. ${ }^{32}$

principles, and therefore did not rely on the ILC.

31 The Court has to decide in accordance with the current law, as evolved in time. Jurisdictional Immunities of the State (Germ. v. It.: Greece intervening), Judgment, 2012 I.C.J. 99, I9 (Feb. 3) (separate opinion of Judge Bennouna) (noting that the codification in the ILC does not preclude further definition, because the task of the Court is to revisit the concepts and norms debated before it and to indicate, if appropriate, any emerging new trends in their interpretation and in the determination of their scope); and Ahmadou Sadio Diallo (Guinea v. Dem.Rep.Congo), Compensation, 2012 I.C.J. 324, 31 (June 19) (separate opinion of Judge Cançado Trinidade).

32 The ILC considered the interpretation of treaties from 1959 to 1964. Art.31 and 32 VCLT were based on six principles found in private writings of the Special Rapporteur, showing that in drafting art.31 and 32 the ILC relied more on logic than on State practice. Rep. of the Int'l Law Comm'n, 16th Sess., May 4-July 19, (1966), U.N. Doc. A/CN.4/181 and A/ CN.4/184; GAOR 18th Sess., Supp. No.9 (1966), reprinted in [1966] 2 Y.B. Int'l L. Comm'n, U.N.Doc. A/23/10, at 220. See Kasikili/Sedudu Island (Bots./Namib), Judgment, 1999 I.C.J. 1045, 18 (Dec. 13) (referring to Territorial Dispute (Libya/Chad), Judgment, 1992 I.C.J. 6, 941 (Feb 3); Islamic Republic of Iran v. United States of America, Preliminary Objections, Judgment, 1996 I.C.J. 812, 923). Cf. Summary Records of the 2585th Meeting, [1999] Y.B. Int'l L. Comm'n 122, U.N.Doc. A/CN.4/SR.2585, para.19. See also Maritime Delimitation and Territorial Questions between Qatar and Bahrain (Qatar v. Bahr.), Jurisdiction and Admissibility, 1995 I.C.J. 6, 27 and 31 (Feb. 15) (separate opinion of Judge Schwebel). 
When developing international law, the Court extends the existing rules of international law and advances the stage of evolution of those rules. ${ }^{33}$ The Court shapes previously unclear norms through interpretation, i.e. by 'crystallizing' pre-customary norms. ${ }^{34}$ However, the Court does not engage in clarifying norms the Court finds to be progressive development of international law. ${ }^{35}$ For example, in the Genocide Case the Court made only a passing reference to draft art.31 on State responsibility and avoided the determination of its status, because the Court considered it to be progressive development by the ILC, despite the fact that the ILC in its Commentary to art.31 cited the same PCIJ decision as the ICJ relied on in its final decision. ${ }^{36}$ Similarly--and perhaps for the same reason--the Court in the Application of the Convention on the Prevention and Punishment of the Crime of Genocide Case, did not afford draft art.6 and 30 on State responsibility any status in international law, as it did with the other draft articles on State responsibility considered in the same case. ${ }^{37}$ However, by invoking draft art. 6 and 30 in its decision, the Court made them more authoritative.

33 See e.g. Advisory Opinion on the Reservations to the Genocide Convention. It is not clear, however, whether the Court developed or progressively developed international law in that Advisory Opinion. North Sea Continental Shelf (Fed. Rep. Germ./Neth.), Judgment, 1969 I.C.J. 3, 232 (Feb. 20) (dissenting opinion of Judge Lachs); Id., at 87 (individual opinion of Judge Padilla Nervo).

34 By interpreting a norm of pre-customary status, the norm becomes a norm of customary international law. See North Sea Continental Shelf (Fed. Rep. Germ./Neth.), Judgment, 1969 I.C.J. 3, 61 (Feb. 20); Id., 181 (dissenting opinion of Judge Tanaka). See e.g. Fisheries Jurisdiction (U.K. v. Ice.), Judgment, 1974, I.C.J. 3, 23 (July 25) (States have the power to 'crystallize' the rules or concepts at the codification conference). See also Summary Records of the 2698st Meeting, [2001] Y.B. Int'l L. Comm'n 208, U.N.Doc. A/CN.4/SR.2698 (referring to Judge Guillaume's statement in the Maritime Delimitation and Territorial Questions between Qatar and Bahrain Case that the Court 'clarified' the law), and Jimenez de Arechaga, supra note 11, at 34 .

35 Fisheries Jurisdiction (U.K. v. Ice.), Judgment, 1974, I.C.J. 3, 44 (July 25) (the Court did not invoke ILC work because it was considered by the Court to be lex ferendae; 'crystallization' of the relevant rule occurred only through subsequent State practice).

36 Application of the Convention on the Prevention and Punishment of the Crime of Genocide (Bosn. \& Herz. v. Serb. \& Montenegro), Judgment, 2007 I.C.J. 43, 460 (Feb. 26) (referring to draft art.31 on State responsibility only in passim as a confirmation of the Court's finding). Ahmadou Sadio Diallo (Guinea v. Dem.Rep.Congo), Compensation, 2012 I.C.J. 324, 1 (June 19) (individual opinion of Judge Cançado Trinidade) (reparation for injuries is progressive development). Int'l L. Comm'n, Draft articles on Responsibility of States for Internationally Wrongful Acts with Commentaries, Rep. of the Int'l L. Comm'n (2001), at 91. The Court did not rely on the same provision in two subsequent judgments, in Djibouti v. France and in Costa Rica v. Nicaragua (the Court could have relied on draft art. 31 on State responsibility). Press Release, I.C.J., Speech by H.E. Judge Rosalyn Higgins, President of the International Court of Justice, at the 59th Session of the International Law Commission (July 10, 2007) (noting the Court's findings were in line with draft art.6 on State responsibility).

37 Press Release, I.C.J., Speech by H.E. Judge Rosalyn Higgins, President of the International Court of Justice, at the 59th Session of the International Law Commission (July 10, 2007). In the Application of the Convention on the Prevention and Punishment of the Crime of 


\section{The Effects of Judicial Legislation}

ICJ's judgments have primary and secondary effects on international lawmaking. Primary effects of the judicial law-making is when the Court's determination that a rule of international law exists, contributes to the clarification or expansion of the body of international norms and rules. Secondary effects of judicial law-making are the result of the Court's influence on the behavior of States, who by following the Court's pronouncement generate new customary norms. Primary effects result from the Court's determination and declaration that a specific rule forms part of customary international law, which States, persistent objectors excluded, are bound to follow. ${ }^{38}$ Only the pronouncements of the status of rules, and not the ICJ judgments per se, become part of customary international law. ${ }^{39}$ The primary effect of judicial legislation is the basis

Genocide Case the Court considered draft art.4, 6, 8, 14, 16, 31 and 58 on State responsibility. The Court noted that draft art.4, 8 and 16 reflected customary international law. The Court did not consider the customary status of draft art. 5, 6, 9 and 11, because the Court said they do not apply in this case. Application of the Convention on the Prevention and Punishment of the Crime of Genocide (Bosn. \& Herz. v. Serb. \& Montenegro), Judgment, 2007 I.C.J. 43, 99385, 406-407, 414, 420 (Feb. 26). Similarly, the Court also in the DRC v. Uganda relied on the test and the definition given by the ILC draft articles on State responsibility, but avoided giving them any clear position in international law. Armed Activities on the Territory of the Congo (Dem. Rep. of the Congo v. Uganda), Judgment, 2005 I.C.J. 168, 160 (Dec. 19).

38 Scholars use the term 'development' which is the same as 'making' because new norms are brought to the international sphere. The Roman maxim iura novit curia and the ICJ Statute, art. 38, para.1, provide that the Court must decide a dispute in accordance with existing international law as it finds it. Shaw, supra note 4 , at $835,839,857$. See also Rao, supra note 4, at 956; Santiago Villalpando, On the International Court of Justice and the Determination of Rules of Law, 26 Leiden J. Int'1 L. 243 (2013), at 243, referring to the Press Release, I.C.J., Speech by H.E. Judge Peter Tomka, President of the International Court of Justice, at the High-level Meeting on the Rule of Law (Sept. 24, 2012); cf. Guillaume, supra note 3, at 859 . The rule the Court declares to be customary might have existed in the international sphere prior to the Court's declaration, but the ICJ's decision turns the rule into lex scripta. Neither the States nor the ILC have such authority as the ICJ to declare a rule to be CIL. The ICJ interprets the current state of law with the possibility it would bind the States with its finding. Cf. Summary Records of the 2585th Meeting, [1999] Y.B. Int'l L. Comm'n 122, U.N.Doc.A/CN.4/SR.2585, para.20; Questions Relating to the Obligation to Prosecute or Extradite (Belg. v. Sen.), 2012 I.C.J. 422, 9144 (July 20), and Sir Michael Wood, Concluding Remarks at the 64th Session of the International Law Commission, Formation and Evidence of Customary International Law (July 30, 2012).

39 Maritime Delimitation in the Area between Greenland and Jan Mayen (Den. v. Nor.), Judgment, 1993 I.C.J. 38, 136 (June 14) (separate opinion of Judge Shahabuddeen) (arguing ICJ should apply rather the treaty provisions as interpreted by the Court, rather than on its precedents); $I d$., at 285 (separate opinion of Judge Ajibola). ICJ clarifies international law and declares a rule to be customary law in its reasoning, and not necessarily in its holdings. For example, the Court in the Application of the Genocide Convention Case invoked draft art.16 on State responsibility and declared it to be customary international law in the dictum of the judgment. Application of the Convention on the Prevention and Punishment of the Crime of Genocide (Bosn. \& Herz. v. Serb. \& Montenegro), Judgment, 2007 
for Court's development of international law, when a finding of customary international law does not result from State practice and opinio juris, but from ILC's Commentaries. ${ }^{40}$ When the Court establishes that the rule is customary law, it will rely on its precedent in future cases, usually without assessing ILC Commentaries (or State practice) anew. ${ }^{41}$

Judicial precedents have also a secondary (non-immediate) effect, when the Court's determination of the State of international law generates State practice and influences scholars. ${ }^{42}$ The ICJ judgments are generally not considered to be binding on States not parties to the dispute, but States, organizations and scholars are influenced by and follow the pronouncements of the Court. ${ }^{43}$ The way that the Court's decisions generate international law is illustrated from the consequences of the Advisory Opinion on Reservations to the Convention on the Prevention and Punishment of the Crime of Genocide. In 1951 both the ILC and the ICJ were tasked by the General Assembly to find the applicable international law on the reservations to multilateral treaties. The ILC surveyed the general State practice and found that the State practice showed that reservations to multilateral treaties cannot be made unless all parties to the multilateral treaty agree with the reservation. ${ }^{44}$ The ICJ, on the other hand, had to find a solution regard-

I.C.J. 43, g9126, 420 (Feb. 26). Similarly, the Court in Gabčikovo-Nagymaros Project said it did not have to apply the VCLT, but nonetheless declared the articles on the termination and the suspension of the operation of treaties in articles 60-62 might be considered as 'codification of existing law.' Gabčikovo-Nagymaros Project (Hung./Slovk.), Judgment, 1997 I.C.J. 7, 46 (Sept. 25). Thirlway, supra note 7, at 434. Once the Court has 'clarified' or 'crystallized' a norm of international law States do not challenge that pronouncement See Shahabuddeen, supra note 14 , at 93 . States could, however, challenge the holding of the Court under art.60 of the ICJ Statute.

40 Schwebel, supra note 3, at 407; Shahabuddeen, supra note 14, at 91. Cf. South West Africa Cases (Eth. v. S. Afr., Liber. v. S.Afr.), Judgment, 1966 I.C.J. 6, 989 (July 18).

41 The ICJ when using the ILC, the ICJ is relying on its precedent rather than on the ILC and the precedent, as considered by the Court is much more authoritative than the work of the ILC. See Maritime Delimitation in the Area between Greenland and Jan Mayen (Den. v. Nor.), Judgment, 1993 I.C.J. 38, 280, 285 (June 14) (separate opinion of Judge Ajibola). The ICJ follows its reasoning from its previous decisions for reasons of coherence. Thirlway, supra note 7, at 434; Schwebel, supra note 3, at 405, 408. See also Certain Questions of Mutual Assistance in Criminal Matters (Djib. v. Fr.), Judgment, 2008 I.C.J. 177, 4 (June 4) (individual opinion of Judge Keith), referring to the Judgment, I145; Rao, supra note 4, at 961; Villalpando, supra note 37, at 245.

42 Maritime Delimitation in the Area between Greenland and Jan Mayen (Den. v. Nor.), Judgment, 1993 I.C.J. 38, 91, 94 (June 14) (separate opinion of Judge Schwebel); Id., 87 (separate opinion of Judge Ranjeva); Villalpando, supra note 37, at 245; Shaw, supra note 4 , at 833 and 843 (also noting the Court's perception of international law bears a great authority, and becomes a predominate approach. Press Release, Statement by H.E. Judge Peter Tomka, President of the International Court of Justice, The Hague International City of Peace and Justice (May 16, 2013).

43 See Schwebel, supra note 7.

44 Int'l L. Comm'n, Reservation to Multilateral Conventions, Rep. of the Int'l L. Comm'n 
ing specifically the possibility of making reservations to the Genocide Convention. In the Court's view, the reservations to multilateral treaties, and hence to the Genocide Convention, could be made even if not all the parties agreed with the reservation being proposed. ICJ's decision, adopting a different approach than the ILC, generated State practice and influenced the practice of the United Nations Secretary-General. These developments led to the change of ILC's position on reservations to multilateral treaties, resulting in the current art.19, 20 and 21 VCLT. $^{45}$

\section{The Pitfalls of International Law-Making}

In theory, the ICJ should survey the international practice on its own, however,

"[i]in practice, the Court has never found it necessary to undertake such an inquiry [of State practice together with opinio juris] for every rule claimed to be customary in a particular case and instead has made use of the best and most expedient evidence available to determine whether a customary rule of this sort exists." ${ }^{46}$

By not relying on State practice in determining customary international law and by relying only on the views expressed by the ILC, the ICJ is de facto 'bypassing' the States' international law-making authority. ${ }^{47}$ In practice, ILC's findings are limited, because the ILC relies on the research conducted by the Special Rapporteur and the preliminary research of the United Nations Secretariat on a specific topic. ${ }^{48}$ For example, in the Application of the Convention on the Prevention and Punishment of the Crime of Genocide Case the Court referred to draft art.16 on State responsibility and declared it to be customary international law without analyzing whether the draft article reflects the actual State practice and opinio juris. ${ }^{49}$ Similarly, in Ahmadou Sadio Diallo Case, while declaring a draft article

(1951), reprinted in [1951] 2 Y.B. Int'1 L. Comm'n, U.N.Doc. A/6/9.

45 First Rep. on the Law of Treaties (1962), at 73 et seqq. See also Reservations to the Convention on the Prevention and Punishment of the Crime of Genocide, Advisory Opinion, 1951 I.C.J. 15, 20 (May, 28). Also the practice of the Secretary-General contributed greatly to a wider acknowledgment of the Court's finding.

46 Tomka, supra note 6, cited in Special Rapporteur on Formation and Evidence in Customary International Law, First report on Formation and Evidence of Customary International Law, Int'l L. Comm'n, U.N. Doc. A/CN.4/663 (May 17, 2013) (by Sir Michael Wood).

47 Schwebel, supra note 3, at 412.

48 Cf. Reservations to the Convention on the Prevention and Punishment of the Crime of Genocide, Advisory Opinion, 1951 I.C.J. 15, at 16 (May, 28) (acknowledging the comprehensive survey of State practice done by the ILC); First Rep. on the Law of Treaties (1962), at 73 et seqq.

49 Application of the Convention on the Prevention and Punishment of the Crime of Genocide (Bosn. \& Herz. v. Serb. \& Montenegro), Judgment, 2007 I.C.J. 43, 420 (Feb. 26). 
of ILC to be customary international law, the Court did not mention any other survey, nor did it cite any other State practice that would confirm its finding. ${ }^{50}$

The Court claims that it carefully considers whether a draft article formulated by the ILC is, in fact, a reflection of customary international law. ${ }^{51}$ Nevertheless, by relying solely on ILC's work, there is a possibility the Court could apply norms that are not yet part of international law. ${ }^{52}$

The Court sometimes relies on the content of draft articles only in substance without referring to a specific ILC provision; or invokes the ILC provision without declaring it to be part of international law. Both of those practices leave the status of the ILC's work unclear. ${ }^{53}$ Although the draft articles influence the reasoning of individual Judges, they don't become part of international law until the Court specifically refers to them in its judgment and declares them to be part of (customary) international law. ${ }^{54}$

On some occasions, the Court decides not to fill the 'gap' in international law with ILC's draft articles, although they are available. ${ }^{55}$ In other instanc-

50 Press Release, I.C.J., Speech by H.E. Judge Rosalyn Higgins, President of the International Court of Justice, at the 59th Session of the International Law Commission (July 10, 2007). "[The Court recalls] that under customary international law, as reflected in Article 1 of the draft Articles on Diplomatic Protection of the International Law Commission..." Ahmadou Sadio Diallo (Guinea v. Dem.Rep.Congo), Preliminary Objections, 2007 I.C.J. 582, 939 (May 24) (emphasis added)

51 Summary Records of the 2585th Meeting, [1999] Y.B. Int'l L. Comm'n 122, U.N.Doc. A/ CN.4/SR.2585, para.19. Villalpando, supra note 37, at 243.

52 Summary Records of the 2585th Meeting, [1999] Y.B. Int'l L. Comm'n 122, U.N.Doc. A/ CN.4/SR.2585, para.18.

53 In Fisheries Jurisdiction Case the Court stated that it "cannot render the judgment sub specia legis ferendae, or anticipate the law before the legislator has laid it down." Fisheries Jurisdiction (U.K. v. Ice.), Judgment, 1974, I.C.J. 3, 53 (July 25). See also Jimenez de Arechaga, supra note 11, at 35-36 (noting the ICJ refused to 'fill the gap' in the Fisheries Jurisdiction Case because UNCLOS III already crystallized the international law in this field). See also Danilenko, supra note 25, at 22 (fn.20), 23 (fn.21). Questions Relating to the Obligation to Prosecute or Extradite (Belg. v. Sen.), 2012 I.C.J. 422, 9931-34 (July 20) (separate opinion of Judge Abraham). See Barcelona Traction, Light and Power Company, Limited, (Belg. v. Spain) (New Application: 1962), Judgment, 1970 I.C.J. 3, 33 (Feb. 5) (the Court did not declare the status of the rule regarding the right of shareholders).

54 For example, the Court in its decision Avena and Other Mexican Nationals Case does not refer to the work of the ILC. However, Judges Tomka, Vereschetin and Sepulveda in their separate opinions flag the fact that ILC's work could be used in this instance. See Schwebel, supra note 21, at 163-164; and Rudolf $\mathrm{H}$. Geigher, Customary International Law in the Jurisprudence of the International Court of Justice: A Critical Appraisal, in From Bilateralism to Community Interest: Essays in Honour of Bruno Simma (2011), at 687 (referring to Gabčikovo-Nagymaros Project, at 50).

55 The Court in the Advisory Opinion on Reservation to the Genocide Convention (1951) did not rely on the survey done by the ILC in reaching its conclusion, although the ILC relied on established practice of the League of Nations, reviewed by the Committee of Experts for the Progressive Codification of International Law of the League of Nations and the practice 
es, the Court pointed out the absence of ILC draft articles that would aid the Court's decision. In the Tunisia/Libya Case, for example, the Court found a rule of international law without the ILC's help, because the ILC did not produce any final work on internal waters (including historical waters and bays). ${ }^{56}$ Similarly, in Frontier Dispute between Benin and Niger, the Court dealt with delimitation of the boundary on bridges over international watercourses in the absence of any bilateral agreement between the two neighboring States, a question the ILC left out of its consideration while drafting what is today the Convention on the Law of the Non-Navigational Uses of International Watercourses. ${ }^{57}$

\section{The Role of the States}

States, the main legislators in international law, should play a predominant role in creating and developing international law. ${ }^{58}$ States are instrumental in facilitating the ICJ-ILC relationship by bringing a claim to the Court on the issue scrutinized by the ILC, and by invoking the ILC draft articles in its submissions to the Court. ${ }^{59}$ However, as a consequence of the Court's reliance on the ILC in finding the applicable rules of international law, States are left out of the lawmaking process. ${ }^{60}$ For example, in Gabčikovo-Nagymaros Project Case, argu-

by the Secretary-General of the United Nations.

56 There were also no relevant provisions in the UNCLOS III Convention. $C f$. North Sea Continental Shelf (Fed. Rep. Germ./Neth.), Judgment, 1969 I.C.J. 3, 89, 90 (Feb. 20) (separate opinion of Judge Padilla Nervo); Id., at 181 (dissenting opinion of Judge Tanaka). The ILC undertook the work on historical waters and bays on the request of the General Assembly in 1959, but never concluded the project. Continental Shelf (Tunis./Libya), Judgment, 1982 I.C.J. 18, 91, 100-101 (Feb. 24). See also Rep. of the Int'l Law Comm'n, 15th Sess., Apr. 25-July 1, (1960), U.N. Doc. A/CN.4/132; GAOR 15th Sess., Supp. No.9 (1960), reprinted in [1960] 2 Y.B. Int'l L. Comm'n, U.N.Doc. A/4425, at 180; Schwebel, supra note 7, at 81.

57 Consequently, the ICJ was unable to rely on the ILC's work. Frontier Dispute (Benin/ Niger), 2005 I.C.J. 90 (July 21). See also Press Release, I.C.J., Speech by H.E. Judge Rosalyn Higgins, President of the International Court of Justice, at the 58th Session of the International Law Commission (July 25, 2006). Convention on the Law of the Non-Navigational Uses of International Watercourses, May 21, 1997, U.N. Doc. A/51/869.

58 State practice and opinio juris generates customary international law, and by adopting treaties, States also generate international treaty obligations. See also Villalpando, supra note 37, at 249 (arguing that the application of the codification depends upon the manner of adoption of the convention by States).

59 Common topics include law of the sea, law of treaties, diplomatic and consular relations, succession of states in relation to treaties, State immunity, State responsibility, diplomatic protection, immunity of state officials from foreign criminal jurisdiction, obligation to extradite and prosecute (aut dedere aut judicare), law of the non-navigational watercourse, prevention of transboundary harm, peace and security of mankind, law of treaties between states and between states and international organizations, expulsion of aliens, arbitral procedure and responsibility of international organizations. However, the Court does not always rely on ILC's work, even though it might cover the same field or question of international law.

60 One State alone cannot create customary international law. See e.g. North Sea Continental 
ments made by Slovakia and Hungary contributed to the Court's finding that the relevant ILC draft articles were part of customary international law. ${ }^{61}$ States also contribute to the international law-making process by expressing their positions at codification conferences, which are considered a legislative history of the draft provision. ${ }^{62}$ States also have the opportunity to modify the ILC draft articles at codification conferences, and to include reservations thereto, before adopting them as a treaty. ${ }^{63}$

Shelf (Fed. Rep. Germ./Neth.), Judgment, 1969 I.C.J. 3, 233-34 (Feb. 20) (dissenting opinion of Judge Lachs); Schwebel, supra note 3, at 405; Rao, supra note 4, at 944.

61 The Court declared art.12 of the Vienna Convention on Succession of States in respect of Treaties to be a customary norm, which was in line with the submissions of Hungary and Slovakia. Gabčikovo-Nagymaros Project (Hung./Slovk.), Judgment, 1997 I.C.J. 7, g123 (Sept. 25). The Court also agreed with States that draft art.30, para.(a) and art.35 on State responsibility in the Jurisdictional Immunities of the State Case are customary international law. However, the Court failed to mention draft art.30, para.(a) and art.35 on State responsibility in the Pulp Mills on the River Uruguay Case although States parties to the dispute invoked those provision. See also Press Release, I.C.J., Speech by H.E. Judge Peter Tomka, President of the International Court of Justice, at the Sixty-fourth Session of the International Law Commission (July 24, 2012).

62 Rao, supra note 4, at 930. Although the United States invoked ILC's Vienna Convention on Diplomatic Relations and draft articles on State responsibility in its submission, the Court did not rely on the ILC. The Court might have avoided referring to the ILC VCDR on diplomatic privileges and immunities because they were considered to be lex lata; the draft articles on State responsibility were still unfinished at the time. Memorial of the United States, United States Diplomatic and Consular Staff in Tehran, U.S. v. Iran), Pleadings, 1979 I.C.J. 21, 157, 160, 162, 164-169, 175, 189, 290, 320 (May 24). United States Diplomatic and Consular Staff in Tehran (U.S. v. Iran), Judgment, 1980 I.C.J. 3, 9946, 67 (May 24).The extensive reliance on draft art. 25 by parties to the dispute in Gabčikovo-Nagymaros Project case contributed to the Court's first reliance on the ILC draft articles on State responsibility. Schwebel, supra note 7, at 68, 75, 163-164. See also Press Release, I.C.J., Speech by H.E. Judge Rosalyn Higgins, President of the International Court of Justice, at the Sixtieth Session of the International Law Commission (July 22, 2008); Geigher, supra note 53, at 685; Tunkin, supra note 24 , at 536 . The research showed only one case the Court considered a draft article of the ILC propio motu. Application of the Convention on the Prevention and Punishment of the Crime of Genocide (Bosn. \& Herz. v. Serb. \& Montenegro), Judgment, 2007 I.C.J. 43, 420 (Feb. 26) (the Court considered propio motu draft art.16 on State responsibility). See also Shaw, supra note 4, at 838 . The Court is not bound to address every argument made before the Court, but can be persuaded by the agreement of the parties in the dispute that a norm is customary international law. Fisheries (U.K. v. Nor.), Judgment, 1951 I.C.J. 116, 152 (Dec 18) (individual opinion of Judge Alvarez).

63 Court's declaration of some ILC draft articles to be customary international law, might influence States not to change such draft articles when adopting a treaty. See Tunkin, supra note 24, at 53; Continental Shelf (Tunis./Libya), Judgment, 1982 I.C.J. 18, 41 (Feb. 24) (separate opinion of Judge Arechaga); Villalpando, supra note 37, at 249, and Sir Michael Wood, The General Assembly and the International Law Commission: What Happens to the Commission's Work and Why?, International Law between Universalism and Fragmentation: Festschrift in Honour of Gerhard Hafner 381 (Isabelle Buffard, James Crawford, Alain Pellet \& Stephan Wittich eds., 2008), at 381 (quoting Chester Brown at the meeting of the Sixth Committee, stating that changing the scope and content of the draft articles on 


\section{The Personal and Formal Aspects of the Relationship Between the International Court of Justice and the International Law Commission}

The ICJ is 'inspired' and "follows' the findings of the ILC. ${ }^{64}$ The Court is mainly referring to treaties prepared by the ILC and to ILC draft articles. ${ }^{65}$

The Court's reliance on the ILC's draft articles demonstrates their (mutually) influential relationship in promoting and developing international law. ${ }^{66}$ While

State responsibility in the event of the adoption of a treaty on State responsibility, would endanger the work of the ILC on this topic).

64 See e.g. Peil, supra note 10, at 136, 155 (2012).

65 Sometimes also to ILC's other instruments, e.g. 'draft codes', 'model rules,' 'principles,' 'conclusions,' 'guidelines', reports of the ILC to the General Assembly and the various reports of the Special Rapporteurs. See Continental Shelf (Libya/Malta), Judgment, 1985 I.C.J. 13, 86 (June 3) (noting the different weight in international law of treaties in force and reties not in force); Gabčikovo-Nagymaros Project (Hung./Slovk.), Judgment, 1997 I.C.J. 7, 72 (Sept. 25); Maritime Delimitation in the Area between Greenland and Jan Mayen (Den. v. Nor.), Judgment, 1993 I.C.J. 38, 61 (June 14) (separate opinion of Judge Oda); Id., at 135 (separate opinion of Judge Shahabuddeen). See also Summary Records of the 1683th Meeting, [1981] Y.B. Int'l L. Comm'n 207, U.N.Doc. A/CN.4/SR; and Summary Records of the 2585th Meeting, [1999] Y.B. Int'l L. Comm'n 122, U.N.Doc. A/CN.4/SR.2585. Treaties not yet in force could be considered to be more authoritative than draft articles. See e.g. Interpretation of the Agreement of 25.3.1951 between the WHO and Egypt, Advisory Opinion, 1980 I.C.J. 73, 9934, 40, 41, 47 (Dec. 20) (both Parties to the dispute and the Director of the United Nations Legal Division asked the Court to consider draft art.56.of the draft articles on the law of treaties between States and international organizations or between international organizations); Id., at 176 (separate opinion of Judge El-Erian) and Id., at 186 (separate opinion of Judge Sette-Cammara). See also Schwebel, supra note 7, at 72. Summary Records of the 1683th Meeting, [1981] Y.B. Int'l L. Comm'n 207, U.N.Doc. A/CN.4/SR.1683. But see Sir Michael Wood, supra note 62. So far, fourteen sets of ILC draft articles have been turned into eighteen conventions and six optional protocols. See International Law Commission, Texts, Instruments and Final reports, available at: http:// legal.un.org/ilc/texts/texts.htm (accessed Nov. 23, 2014); Summary Records of the 2503rd Meeting, [1997] Y.B. Int'l L. Comm'n 207, U.N.Doc. A/CN.4/SR.2503. Instruments other draft articles have less possibilities of becoming international law, because they are not designed to be adopted by States. The Court, for example, acknowledged the ILC's Nuremberg principles and the Declaration of the Rights and Duties of States as a contribution of the ILC to the Convention on the Prevention and Punishment of the Crime of Genocide. The General Assembly gave both the ILC and ECOSOC the same task. Application of the Convention on the Prevention and Punishment of the Crime of Genocide (Bosn. \& Herz. v. Serb. \& Montenegro), Judgment, 2007 I.C.J. 43, 99163,173 (Feb. 26).

66 Press Release, I.C.J., Statement by H.E. Judge Peter Tomka, President of the International Court of Justice, The Hague International City of Peace and Justice (May 16, 2013). Villalpando, supra note 37, at 247. See also Peil, supra note 10, at 152. Summary Records of the 2813rd Meeting, [2004] Y.B. Int'l L. Comm'n 153, U.N.Doc. A/CN.4/SR.2813; Provisional Summary Records of the 3100th Meeting, [2011] Int'l L. Comm'n, U.N. Doc. A/CN.4/ SR.3100, Statute of the International Law Commission, art.11, para.1 (1947). The results of the research show that both the ICJ and the ILC considered questions related to the law of the sea, law of treaties, legal effect of the unilateral declarations, the most favored nation clause, diplomatic and consular law (including the consideration of diplomatic asylum), 
their interaction is not institutionalized the personal bond between the two institutions is strong. ${ }^{67}$ A number of ICJ Judges were previously ILC members, bringing to the Court the experience accumulated at the ILC and the insight of ILC's work. ${ }^{68}$ ILC members also participate in the Court's proceedings by acting as counsels of States in disputes before the Court. ${ }^{69}$

The only formal aspects of the relationship between the institutions are the annual visits of the ICJ President to ILC sessions. Those sessions facilitate a direct exchange of opinions between the ICJ and the ILC. ${ }^{70}$ Interestingly, the ICJ President paid his first visit to the ILC only one year before rendering the decision in North Sea Continental Shelf Case, which was also the first case in which the Court closely analyzed ILC's work. ${ }^{71}$ However, the visit of the President of the Court did not become a regular practice until 1997, the same year when the Court rendered its decision in Gabčikovo-Nagymaros Project Case, in which it extensively referred to the ILC draft articles on State responsibility. ${ }^{72}$

State responsibility, responsibility of international organizations, international environmental law, among others.

67 The institutionalization of the relationship might limit both institutions in collecting and assessing the evidence and the sources of international law.

68 Continental Shelf (Tunis./Libya), Judgment, 1982 I.C.J. 18, 48 (Feb. 24) (separate opinion of Judge Jimenez de Arechaga). Press Release, Statement by H.E. Judge Peter Tomka, President of the International Court of Justice, The Hague International City of Peace and Justice (May 16, 2013). See also Villalpando, supra note 37, at 247. Thirty-five out of hundred and three Judges of the ICJ were members of the ILC, nine among them were also elected as Presidents of the Court. Press Release, I.C.J., Speech by H.E. Judge Rosalyn Higgins, President of the International Court of Justice, at the Sixtieth Session of the International Law Commission (July 22, 2008). See Press Release, I.C.J., Speech by H.E. Judge Peter Tomka, President of the International Court of Justice, at the Sixty-fourth Session of the International Law Commission (July 24, 2012). Only Judge Ferrari Bravo became an ILC member after serving as an ICJ judge. Twenty-three out of hundred and six ad hoc Judges were ILC members.

69 Peil, supra note 10 , at 161.

70 The direct dialogue between the institutions that might harmonize the differences in interpretation of certain rules of international law. The President of the Court sometimes highlights the issues the Commission could consider researching. Direct exchange between the ILC members and the ICJ Judge is established in informal discussions following the address.

71 First documented visit of the Judge of the ICJ to the ILC took place in 1968, a year before the Court rendered its decision in the North Sea Continental Shelf. Summary Records of the 971st Meeting, [1968], Y.B. Int'l L. Comm'n 161, U.N.Doc. A/CN.4/SR.971.

72 Gabčikovo-Nagymaros Project (Hung./Slovk.), Judgment, 1997 I.C.J. 7 (Sept. 25). The Judges of the Court were present at 971st, 1004th, 1068th, 1683th, 2503rd, 2538th, 2585th, 2658th, 2698st, 2739th, 2775th, 2813rd, 2851st, 2899th, 2933rd, 2982nd, 3016th, 3062nd, 3100th and 3148th meeting of the ILC. 


\section{The Relationship Between the International Court of Justice and the International Law Commission Over Time}

In the period from 1949 to 1968 , when the ILC began drafting its first draft articles, only individual Judges acknowledged ILC's existence. ${ }^{73}$ The Court first acknowledged ILC's existence in the Advisory Opinion on Reservations to the Convention on the Prevention and Punishment of the Crime of Genocide. However, the ICJ disagreed with the conclusions reached by the ILC on issues of reservations to multilateral treaties. ${ }^{74}$ The Court eventually started referring to the ILC as a 'juridical project', and in North Sea Continental Shelf Case the Court used ILC's work as an aid in determining the customary status of particular rules. ${ }^{75}$

The Court started increasingly referring to the work of the ILC over the years, ${ }^{76}$ but the Court's reliance on ILC draft articles, as opposed to the treaties

73 Summary Records of the 2585th Meeting, [1999] Y.B. Int'l L. Comm'n 122, U.N.Doc. A/ CN.4/SR.2585, para 19. The ICJ was familiar with the ILC's work since its inception. Three Judges of the Court helped drafting the ILC Statute. Summary Records of the 971st Meeting, [1968], Y.B. Int'l L. Comm'n 161, U.N.Doc. A/CN.4/SR.971. See e.g. "Reference must also be made to ... the works of the [International Law] Codification Commission set up by the United Nations ... These are the new elements on which the new international law, still in the process of formation, will be founded." Fisheries (U.K. v. Nor.), Judgment, 1951 I.C.J. 116, 149 (Dec 18) (individual opinion of Judge Alvarez).

74 In 1950 the General Assembly gave a similar mandate both to the ILC and the ICJ in regards to the reservation to multilateral treaties. See G.A. Res. 478/V at 74 (Nov. 16, 1950). The ICJ and the ILC expressed conflicting views on reservations to multilateral treaties. The ILC surveyed State practice and practice of the League of Nations, whereas the ICJ adopted a practical view, reflecting the current practice of some States. With the help of the Secretary-General, a depositary of the numerous multilateral treaties, the League of Nations adopted ICJ's approach. The ICJ advisory opinion was with modifications adopted and incorporated by the ILC in its draft articles on the law of treaties.

75 Despite the extensive considerations of the article's drafting history on 18 pages, the Court in North Sea Continental Shelf Case did not find art.6 of the 1958 Geneva Convention on the Continental Shelf, drafted by the ILC, to be customary international law, mainly because of the discussions which took place at the ILC during which the provision was drafted. North Sea Continental Shelf (Fed. Rep. Germ./Neth.), Judgment, 1969 I.C.J. 3, 33-51 (Feb. 20). Judge Padilla-Nervo, Judge Lachs, Judge Fouad Ammoun, Judge Tanaka, Judge ad hoc Sorensen, Vice-President Koretsky, and Judge Jessup also noted the ILC work in their individual opinions. Judge Padilla Nervo's separate opinion dedicates nine pages of consideration of ILC's work. Id., at 86-98 (separate opinion of Judge Padilla Nervo). Incidentally, in 1968 the President of the ICJ delivered its first official speech, that later transformed into an established practice. See also Rachmaran, supra note 14, at 56, 95 (emphasizing the importance of the 'judicial' recognition of the work of the ILC); North Sea Continental Shelf (Fed. Rep. Germ./Neth.), Judgment, 1969 I.C.J. 3, 48 (Feb. 20) (reference to the ILC as 'juridical project' in ILC's work on historical waters and bays). See also General Assembly Resolution 1453 (XIV) on the Study of the Juridical Regime of Historic Waters, including Historic Bays: Note by the Secretariat, UN Doc. A/CN.4/126 (1960, vol. II).

76 In this period, the Court mainly transplanted the treaty provisions into customary international law. The ILC produced fifteen draft conventions, later adopted as treaties at codifica- 
adopted ased on ILC's work, became more regular only after 1997, when the Court decided the Gabčikovo-Nagymaros Project The Court then began to consider ILC draft articles as evidence of customary international law. ${ }^{77}$ The chart below shows the decisions in which the Court referred to the ILC in different time periods:

Chart: Approximate
number of ICJ cases
and individual opin-
ions, in different peri-
ods, referring to the ILC
work.

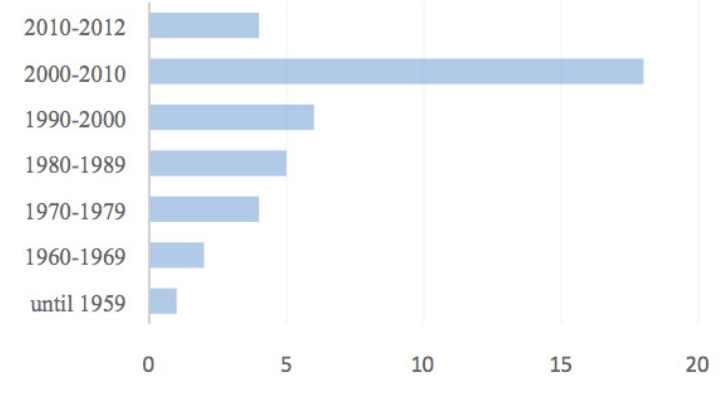

tion conferences. The codification conventions gave a major role to the States because it enabled the States to modify or to clarify the draft convention prepared by the ILC. See also Huikang, supra note 19, at 306. The first two decades of the ILC's existence were termed the 'golden age' of the ILC. See Speech by Edwige Belliard, Report of the International Law Commission on the work of its sixtieth session; General Observations (Oct. 29, 2008). Press Release, I.C.J., Speech by H.E. Judge Rosalyn Higgins, President of the International Court of Justice, at the 59th Session of the International Law Commission (July 10, 2007). In the period from 2003 to 2009 the Court used ILC's work in eight out of 26 cases. Provisional Summary Records of the 3016th Meeting, [2009] Y.B. Int'l L. Comm'n, U.N.Doc. A/CN.4/SR.3016. Between 1949 and 1968, the ICJ issued 51 decisions (decisions on preliminary objections and merits, and orders) and 13 advisory opinions (total of 34 disputes were brought to the Court); between the years 1969 and 1996 the ICJ issued 43 decisions and nine advisory opinions (total of 31 disputes were brought to the Court); and in the years 1997 to 2012 the ICJ issued 72 decisions and four advisory opinions (the total of 53 disputes were brought to the Court). See International Court of Justice website, available at: http://www.icj-cij.org/docket/index.php?p1=3 (accessed July 25, 2014).

77 The Court referred to a ILC draft articles before the year 1997 in Interpretation of the Agreement of 25.3.1951 between the WHO and Egypt, Advisory Opinion, 1980 I.C.J. 73 (Dec. 20), Certain Phosphate Lands in Nauru (Nauru v. Austl.), Preliminary Objections, 1992 I.C.J. 240 (June 26), and in the Application of the Convention on the Prevention and Punishment of the Crime of Genocide (Bosn. \& Herz. v. Serb. \& Montenegro), Preliminary Objections, 1996 I.C.J.595 (July 11). Schwebel, supra note 7, at 72; Press Release, I.C.J., Speech by H.E. Judge Peter Tomka, President of the International Court of Justice, at the Sixty-fourth Session of the International Law Commission (July 24, 2012); Summary Records of the 2775th Meeting, [2003] Y.B. Int'l L. Comm'n 163, U.N.Doc. A/CN.4/SR.2775 (noting that the Court relied on the draft articles four years before they were adopted on the second reading); Gabčikovo-Nagymaros Project (Hung./Slovk.), Judgment, 1997 I.C.J. 7, 47 (Sept. 25). The decision in Gabčíkovo-Nagymaros Project Case also coincides with the period when the annual visits of the President of the ICJ to the ILC became an 'established practice.' Up to the year 1997 the President of the ICJ visited the ILC on five occasions. Rep. of the Int'l Law Comm'n, 65th Sess., May 6- June 7, July 8-Aug.9, (2013), U.N. Doc. A/CN.4/656. 
A possible explanation of the Court's increased reliance on ILC draft articles might be the current lack of interest of States in transforming the ILC work into new treaties. ${ }^{78}$

\section{The Relationship Between the International Court of Justice and the International Law Commission: Findings}

The ICJ does not have a uniform approach when it considers the ILC's work. The ICJ's approach depends on whether the ILC has referred to the ICJ in its Commentaries, whether the parties to the dispute referred to the ILC draft articles in their pleadings, and whether States adopted the ILC draft articles into a treaty. The Court in 'elevating' or 'transplanting' ILC's work into customary international law also considers the number of signatories to a particular treaty, the topic, the number of years the ILC has considered a particular topic, and-of course-and the conformity of the ILC's work with the ICJ's jurisprudence. ${ }^{79}$

\section{When does the ICJ Rely on ILC's Work?}

The Court relies on ILC's work when it agrees with the conclusion reached by the ILC, and when the draft provision is lex lata. The ICJ lends its support to the ILC's draft instruments, when the ILC, in arriving at its conclusions, relied on ICJ's or PCIJ's jurisprudence. ${ }^{80}$ When the ILC refers to the PCIJ's or ICJ's decisions, the Court relies on the ILC to support and to expand in its findings, and to confirm its precedents, which results in a circular reference.

Other factors that the ICJ considers when it decides whether to rely on the ILC are the length of the ILC's consideration of a particular topic and the quality of the research conducted by the Special Rapporteurs. ${ }^{81}$ However, the ICJ's reli-

78 Only two treaties drafted by the ILC were adopted between 1997 and 2012-Convention on the Law of the Non-Navigational Uses of International Watercourses (1997), U.N. Doc. A/51/869 and the United Nations Convention on Jurisdictional Immunities of States and Their Property (2004), U.N. Doc. A/59/508.

79 In drafting draft art.33 on State responsibility, the ILC relied on the jurisprudence of international and domestic tribunals. Int'l L. Comm'n, Draft articles on Responsibility of States for Internationally Wrongful Acts with Commentaries, Rep. of the Int'l L. Comm'n (2001), at 80-81 (Commentary to art.25); Rep. of the Int'l Law Comm'n, 30th Sess., May 5-July 25, (1980), U.N. Doc. A/CN.4/326; GAOR 32nd Sess., Supp. No.10 (1980), reprinted in [1980] 2 Y.B. Int'l L. Comm'n, U.N.Doc. A/35/10, at 42 (in considering draft art.25 on 'state of necessity' the ILC dedicated only one page out of thirty-eight to State practice).

80 Certain Questions of Mutual Assistance in Criminal Matters (Djib. v. Fr.), Judgment, 2008 I.C.J. 177, 94-6 (June 4) (separate opinion of Judge Keith); Avena and Other Mexican Nationals (Mex. v. U.S.), Judgment, 2004 I.C.J. 12, 6 (March 31) (separate opinion of Judge Vereshchetin). See also Provisional Summary Records of the 2933rd Meeting, [2007] Y.B. Int'l L. Comm'n, U.N.Doc. A/CN.4/SR.2933 (noting the ICJ refers to the ILC when they share the same view); Press Release, I.C.J., Speech by H.E. Judge Rosalyn Higgins, President of the International Court of Justice, at the 59th Session of the International Law Commission (July 10, 2007).

81 Longer consideration of a topic by the ILC gives the States more opportunity to participate 
ance on these factors is not consistent. A comparison of the results of analyzing the ICJ's extensive reliance on the ILC's work in the fields of State responsibility and law of the sea, shows a striking resemblance in ICJ's approach towards the ILC's work in the two fields. ${ }^{82}$ The Court has widely cited the ILC's work in both the area of law of the sea and State responsibility, despite the fact that, unlike the Geneva Conventions on the Law of the Sea, the draft articles on State responsibility are still non-binding. The law of the sea was also the topic the ILC considered for the shortest period of time, in comparison to its consideration of State responsibility, which was on the ILCs agenda the longest-forty years. ${ }^{83}$

The Court generally relies on the ILC's work when the ICJ determines that the draft article is part of lex lata. ${ }^{84}$ In Gabcikovo-Nagymaros Project Case the

in the drafting process, either by submitting comments and suggestions or by generating State practice. The ICJ, for example, relied extensively on the draft articles on State responsibly, a topic considered by the ILC for 40 years; but the Court did not rely so extensively on the topic of the international watercourse, which was considered by the ILC for nearly twenty years. The later approach adopted by the Court might have resulted from the perception that the ILC work on was development of international law. Press Release, I.C.J., Speech by H.E. Judge Rosalyn Higgins, President of the International Court of Justice, at the Sixtieth Session of the International Law Commission (July 22, 2008). Time is, however, not the only factor. Although the ILC considered the topic of the law of the sea only seven years, the Court relied extensively on the four conventions drafted by the ILC. Special Rapporteurs are not bound to follow any standards in surveying international law on a particular topic and often do not survey the whole field of international law in preparation of proposed draft articles. Neither the ILC, nor its secretariat, has not adopted any standards in how a Special Rapporteur should survey international law. See also Sir Michael Wood, supra note 62, at 380 and 383.

82 Both the topic of the sea and State responsibility are of symbolic importance. The Court relied on the first time on ILC's treaty in North Continental Shelf Case; and in GabčikovoNagymaros Project, the Court relied for the first time on ILC's draft articles. See also Rachmaran, supra note 14, at 95. One of the first references to the work of the ILC on the topic of State responsibility was in the individual opinion of Judge Shahabuddeen in Certain Phosphate Lands in Nauru. Certain Phosphate Lands in Nauru (Nauru v. Austl.), Preliminary Objections, 1992 I.C.J.240, 284 (June 26) (individual opinion of Judge Shahabuddeen).

83 The topic of the law of the sea was considered to be lex ferendea, draft articles on State responsibility are mostly considered to be mostly lex lata. The draft articles later to constitute the four Geneva Conventions on the law of the sea were considered by the ILC for the shortest time (from 1949 to 1956), whereas the topic on State responsibility was considered the longest (almost 40 years, from 1954 to 2001) - and the draft articles have not been yet adopted as a convention. See also Schwebel, supra note 3, at 406; Application of the Convention on the Prevention and Punishment of the Crime of Genocide (Bosn. \& Herz. v. Serb. \& Montenegro), Judgment, 2007 I.C.J. 43, 48 (Feb. 26) (individual opinion of Judge Mahiou); Summary Records of the 2585th Meeting, [1999] Y.B. Int'l L. Comm'n 122, U.N.Doc. A/CN.4/SR.2585; Summary Records of the 2775th Meeting, [2003] Y.B. Int'l L. Comm'n 163, U.N.Doc. A/CN.4/SR.2775; Press Release, I.C.J., Speech by H.E. Judge Rosalyn Higgins, President of the International Court of Justice, at the 59th Session of the International Law Commission (July 10, 2007).

84 Gabčikovo-Nagymaros Project (Hung./Slovk.), Judgment, 1997 I.C.J. 7, 999 (Sept. 25); Ahmadou Sadio Diallo (Guinea v. Dem.Rep.Congo), Preliminary Objections, 2007 I.C.J. 
Court declared art.12 of the Vienna Convention on Succession in Respect to Treaties to be customary international law, but it refrained from doing so in regards to art.34 of the same convention. The Court determined that art.34 had not yet attained the status of customary norm at the time the Court rendered its decision..$^{85}$

A single draft article can contain both lex lata and de lege ferenda elements. For example, the Court in Costa Rica v. Nicaragua and in Germany v. Italy considered draft art.30, paras.(a) and (b) on State responsibility and found the two paragraphs of the same draft article have different status in international law. ${ }^{86}$ In another instance, Judge Roucounas in the Application of the Interim Accord of 13 September 1995 Case noted that draft art.52, para.1 on State responsibility contained some lex lata elements that extend beyond the scope of customary international law. ${ }^{87}$

Although the ICJ might not always accept the ILC de lege federndae provisions, the Court considers itself competent to progressively develop international law. In the Legal Status of Eastern Greenland Case the PCIJ declared that an oral statement made by the Minister of Foreign Affairs has a binding effect in international law, if it is of considerable importance for the State ${ }^{88}$ In determining the relevant international rule, the Court considered the nature of the reply,

582, 634 (May 24) (separate opinion of Judge Mampuya) (confirming the Court fulfils its task in solving international disputes by positive international law de lege lata); Summary Records of the 2585th Meeting, [1999] Y.B. Int'l L. Comm'n 122, U.N.Doc. A/CN.4/SR.2585, para.19 (confirming the Court relies on articles that it considers to be customary international law, e.g. rules regarding countermeasures and state of necessity). The Court relies on ILC's preparatory work of a treaty in force between the parties in the dispute before the Court. The Court refrains from relying on the legal instruments the Court determines to be de lege ferendae. Ahmadou Sadio Diallo (Guinea v. Dem.Rep.Congo), Preliminary Objections, 2007 I.C.J. 582, 621 (May 24) (declaration of Judge ad hoc Mahiou) (implying the Court was careful in scrutinizing art.11 on Diplomatic protection-the Court, not wanting to act as a legislator in considering this de lege ferendae provision, considered the reactions of the States). Only on some occasions the Court considered draft articles representing a norm evolving from a pre-customary norm to a customary rule.

85 Only certain provisions scrutinized by the Court were considered to be customary international law, and not the convention as a whole. Gabčikovo-Nagymaros Project (Hung./ Slovk.), Judgment, 1997 I.C.J. 7, gg123-124 (Sept. 25).

86 Dispute regarding Navigational and Related Rights (Costa Rica v. Nicar.), Judgment, 2009 I.C.J. 213, 150 (July 13) (the Court did not cite art.30, para.(b) on non-repetition, it referred only to its substance in the Judgment without expressing its views on the nature of the art.30, para.(b), drafted by the ILC); and Jurisdictional Immunities of the State (Germ. v. It.: Greece intervening), Judgment, 2012 I.C.J. 99, 137 (Feb. 3) (the Court declared draft art.30, para.(a) on cessation was reflective of general international law on State responsibly).

87 Application of the Interim Accord of 13 September 1995 (Maced. v. Greece), Judgment, 2011 I.C.J. 644 (Dec. 5) (the Court in rendering its decision did not rely on the draft articles on State responsibility); Id., 972 (dissenting opinion of Judge ad hoc Roucounas).

88 Lauterpacht, supra note 10, at 210-11. 
the fact that it was given on behalf of the government in response to a diplomatic representative of another government, and that the statement was within the scope of the Minister's functions. ${ }^{89}$ There was no rule of international law that would support such contention made by the Court, confirmed by the silence of the scholars on this particular matter. The Court by clarifying this norm of international law, it also progressively developed international law on its own..$^{90}$

The Court relies on the ILC's work when the draft provisions support or reflect previous findings of the Court. ${ }^{91}$ Also individual Judges often seek confirmation of their opinion in the ILC's work or even in the statements made during the ILC annual sessions. ${ }^{92}$ This type of cross-reliance leads to instances of 'circular reference,' when the Court cites the ILC draft articles or commentary thereof in which the ILC refers to the jurisprudence of the ICJ or PCIJ, even though the ILC findings do not necessarily reflect the current customary international law. ${ }^{93}$ Gabčikovo-Nagymaros Project provides a striking example of such 'circular

89 Legal Status of Eastern Greenland, Judgment, 1933 P.C.I.J. 22, 71 (April 5).

90 The Court with this proclamation created a rule and guidance, not only for Denmark and Norway (parties in the dispute before the Court), but also for States which did not necessarily have an established practice of oral undertakings by the Minister for Foreign Affairs.

91 See e.g. Continental Shelf (Libya/Malta), Judgment, 1985 I.C.J. 13, g962-63 (June 3) (noting the evolving law on continental shelf); Maritime Delimitation in the Area between Greenland and Jan Mayen (Den. v. Nor.), Judgment, 1993 I.C.J. 38, g955, 136 (June 14); and Id., 134 (separate opinion of Judge Shahabuddeen); Geigher, supra note 53, at 689; and Villalpando, supra note 37, at 245. "The International Law Commission was of the same opinion when it explained that it had opted for a negative form of words in Article 33 of its Draft..." Gabčikovo-Nagymaros Project (Hung./Slovk.), Judgment, 1997 I.C.J. 7, 51 (Sept. 25) (emphasis added). The Court for example agreed with the Commission's differentiation between preparatory actions in international law and the offences as such in the Gabčikovo-Nagymaros Project, and in the sign of its approval-and confirmationreferred to the Commentary to the draft art.41 on State responsibility in its decision. Id., 979. Similarly, the Court in Jurisdictional Immunities of the State Case in analyzing whether the relevant provisions of the United Nations Convention on Jurisdictional Immunities of States and Their Property relied on the draft articles on State responsibility and its Commentary to 'expand on its findings.' Press Release, I.C.J., Speech by H.E. Judge Peter Tomka, President of the International Court of Justice, at the Sixty-fourth Session of the International Law Commission (July 24, 2012). See also Certain Questions of Mutual Assistance in Criminal Matters (Djib. v. Fr.), Judgment, 2008 I.C.J. 177, 4 (June 4) (declaration of Judge Keith).

92 For example, five Judges in the Nuclear Tests Cases referred to the ILC preparatory work in confirming their interpretation of the VCLT, when it was still not in force. Nuclear Tests (Australia v. France), Judgment, 1974 I.C.J. 235, 337-338 (Dec. 20) (joint dissenting opinion of Judges Bengzon, Onyeama, Dillard, Jimenez de Arechaga, and Sir Humprey Waldock). Judge Al-Khasawneh in the Application of the Convention on the Prevention and Punishment of the Crime of Genocide relied only on the views expressed by some ILC members, while omitting the reference to other members. Application of the Convention on the Prevention and Punishment of the Crime of Genocide (Bosn. \& Herz. v. Serb. \& Montenegro), Judgment, 2007 I.C.J. 43, 33 (Feb. 26) (dissenting opinion of Judge AlKhasawneh).

93 The Court relied positively on draft art. 12 in assessing Diallo's claim, because the ILC 
reference.' The Court referred to the Vienna Convention on State Succession in Respect to Treaties and to the ILC's preparatory work. ${ }^{94}$ Although the Convention was adopted in 1978 and has to this day only few signatories, both parties argued that art.12 of the Vienna Convention reflected customary international law. ${ }^{95}$ The ILC itself considered this provision to reflect mainly progressive development of international law. In its Commentary to draft art.12 the ILC relied on the ICJ and PCIJ decision, and it did not cite any State practice in support of its conclusions. ${ }^{96}$ Despite the position of the ILC on the international status of the provision codified as art.12, the Court nevertheless declared art.12 to be customary international law. ${ }^{97}$ In finding that art.12 is customary international law, the Court relied solely on the 1974 ILC Commentary to draft art.12 (which confirmed the ICJ's case-law). The ILC also omitted any reference to State practice. ${ }^{98}$

while drafting art. 12 on diplomatic protection relied on the Court's Barcelona Traction Case. Ahmadou Sadio Diallo (Guinea v. Dem.Rep.Congo), Preliminary Objections, 2007 I.C.J. 582, 54 (May 24) (see Guinea’s submission before the Court); Id., 2 (declaration of Judge ad hoc Mahiou); Press Release, I.C.J., Speech by H.E. Judge Rosalyn Higgins, President of the International Court of Justice, at the 59th Session of the International Law Commission (July 10, 2007). The ILC routinely refers to ICJ's or PCIJ's jurisprudence. See e.g. Avena and Other Mexican Nationals (Mex. v. U.S.), Judgment, 2004 I.C.J. 12, gg21-22 (March 31) (separate opinion of Judge Parra-Aranguren). Circular references are not confined to the ICJ-ILC relationship, but extend also to municipal systems, when the ILC cites municipal decisions that referred to the ILC. Jurisdictional Immunities of the State (Germ. v. It.: Greece intervening), Judgment, 2012 I.C.J. 99, 992, 5 (Feb. 3) (dissenting opinion of Judge ad hoc Gaja).

94 Vienna Convention on Succession of States in respect of Treaties, art.12, Aug. 23, 1978 1946 U.N.T.S. 3. Int'1 L. Comm'n, Draft articles on Succession of States in respect of Treaties with Commentaries, Rep. of the Int'l L. Comm'n (1974), reprinted in [1974] 2 Y.B. Int'l L. Comm'n, U.N.Doc. A/9610/REV.1.

95 Gabčikovo-Nagymaros Project (Hung./Slovk.), Judgment, 1997 I.C.J. 7, g9119-120 (Sept. 25). The Convention has only 22 States parties and 19 states signatories. United Nations Treaty Collection, available at http://treaties.un.org/Pages/ViewDetails. aspx?src=TREATY\&mtdsg_no=XXIII-2\&chapter=23\&lang=en (accessed Aug.5, 2013).

96 The ILC in drafting art.12 claimed it relied on the ICJ and PCIJ's case-law, writings of scholars and State practice. However, the ILC did not analyze State practice in its Commentaries. Int'l L. Comm'n, Draft articles on Succession of States in respect of Treaties with commentaries, Rep. of the Int'l L. Comm'n (1974), reprinted in [1974] 2 Y.B. Int'l L. Comm'n, U.N.Doc. A/9610/REV.1, at 196. "The proceedings of international tribunals throw some light on the question of territorial treaties. In its second Order in the case concerning the Free Zones of Upper Savoy and the District of Gex the Permanent Court of International Justice made a pronouncement which is perhaps the most weighty [sic] endorsement of the existence of a rule requiring a successor State to respect a territorial treaty affecting the territory to which a succession of States relates." (emphasis added). Id., at 197.

97 Huikang, supra note 19, at 122; Gabčikovo-Nagymaros Project (Hung./Slovk.), Judgment, 1997 I.C.J. 7, 123 (Sept. 25). Only Slovakia was a party to the treaty. See also Schwebel, supra note 7 , at $89-90$.

98 The Court does not rely on PCIJ's decisions, the ILC analyzed in the Commentary to the draft art.12. Gabčikovo-Nagymaros Project (Hung./Slovk.), Judgment, 1997 I.C.J. 7, 71-72 (Sept. 25) (citing to the Draft articles on Succession of States (1974) at 33). See also Summary 
Another similar example can be found in the Application of the Convention on the Prevention and Punishment of the Crime of Genocide Case, where the Court re-asserted the validity of the 'effective control' test. ${ }^{99}$ The 'effective control' test was established in Military and Paramilitary Activities in and against Nicaragua Case, and was challenged by the International Criminal Tribunal for the Former Yugoslavia (ICTY) in Prosecutor v. Tadić. The ICTY opted for the 'overall control' test, and not for the 'effective control' test. ${ }^{100}$ The ICJ in Application of the Convention on the Prevention and Punishment of the Crime of Genocide Case confirmed its 'effective control' test over the ICTY's 'overall control' test. The Court found the confirmation for its decision in the draft art.8 on State responsibility, which the ICJ declared to reflect customary international law. ${ }^{101}$ While drafting art. 8 the ILC considered both the ICJ and the ICTY's tests and balanced both approaches, but it eventually favored the ICJ's 'effective control' test. ${ }^{102}$ Although responsibility of States differs from individual criminal responsibility, which may explain relying on different control tests, the Court in Application of the Convention on the Prevention and Punishment of the Crime of Genocide Case omitted any reference to the ILC deliberations, and considered the ILC Commentary as confirming only the ICJ's 'effective control' test. ${ }^{103}$

The Court always cites first its own or PCIJ decisions before mentioning ILC's work. ${ }^{104}$ But despite ILC's reference to the PCIJ or ICJ decisions, the Court

Records of the 2775th Meeting, [2003] Y.B. Int'l L. Comm'n 163, U.N.Doc.A/CN.4/SR.2775; Schwebel, supra note 21, at 163.

99 As established in Military and Paramilitary Activities in and Against Nicaragua Case, and confirmed in the Application of the Genocide Convention Case. Application of the Convention on the Prevention and Punishment of the Crime of Genocide (Bosn. \& Herz. v. Serb. \& Montenegro), Judgment, 2007 I.C.J. 43, 401 (Feb. 26).

100 See e.g. Prosecutor v. Tadic, International Criminal Tribunal for the Former Yugoslavia (Appeals Chamber), 1999 Judgment 49, 9120.

101 Application of the convention on the Prevention and Punishment of the Crime of Genocide (Bosn. \& Herz. V. Serb. \& Montenegro), Judgment, 2007 I.C.J. 43, g9401, 414.

102 The ILC was critical to the 'effective control' test as established in the Nicaragua v. U.S. Case, but could not follow the ICTY's 'overall control' test due to the inherent difference between individual criminal responsibility and State responsibility. Int'l L. Comm'n, Draft articles on Responsibility of States for Internationally Wrongful Acts with Commentaries, Rep. of the Int'l L. Comm'n (2001), reprinted in [2001] 2 Y.B. Int'l L. Comm'n, U.N.Doc. A/56/10 \& Corr.1, at 48.

103 "[Article 8 of the ILC Articles on State Responsibility] must be understood in the light of the Court's jurisprudence on the subject, particularly that of the 1986 Judgment in the case concerning Military and Paramilitary Activities in and against Nicaragua..." (emphasis added). Application of the Convention on the Prevention and Punishment of the Crime of Genocide (Bosn. \& Herz. v. Serb. \& Montenegro), Judgment, 2007 I.C.J. 43, g9398-399 (Feb. 26). See also Press Release, I.C.J., Speech by H.E. Judge Rosalyn Higgins, President of the International Court of Justice, at the 59th Session of the International Law Commission (July 10, 2007) and Geigher, supra note 53, at 686.

104 The Court rarely considers also the consistency of its decisions with decisions by regional courts. In one such instance the ICJ consulted European Court of Human Rights' and 
can also decide not to apply a particular ILC provision. The Court usually omits any reference to the ILC when it disagrees with the findings of the ILC. In such cases the Court usually claims the provision is not yet ripe to become a rule of customary international law, or does not mention the ILC draft provision at all.

For example, in Ahmadou Sadio Diallo Case (Comp.), the Court considered draft art.31 on State responsibility to be de lege ferendae, despite ILC's Commentary referring to PCIJ's Factory of Chorzow Case, and ILC's reassurances that the norm codified in art.31 of State responsibility was a generally accepted rule of international law. ${ }^{105}$ Despite the ILC's reliance on the same case the Court referred to in Ahmadou Sadio Diallo Case, the Court did not rely on art.31. In Ahmadou Sadio Diallo Case (Prelim. Obj.), the Court failed to mention ILC's draft art.14 on Diplomatic protection, although the ILC relied on the same cases as invoked by the ICJ in rendering its decision. ${ }^{106}$ The Court's approach to ILC work in Ahmadou Sadio Diallo Case indicates that the Court interprets ILC's draft articles in accordance with its own findings as laid out in the ICJ's or PCIJ's jurisprudence, regardless of ILC's findings.

However, when the Court agrees with the ILC's interpretation of international law as codified in its draft provisions, the Court relies on ILC's work to affirm its own jurisprudence. In the Armed Activities on the Territory of the Congo Case the Court stated that waivers should be either 'express' or 'unequivocally implied,'

Inter-American Court of Human Rights' case-law for the purpose of establishing forms of non-pecuniary injury to a person in international law. Ahmadou Sadio Diallo (Guinea v. Dem.Rep.Congo), Compensation, 2012 I.C.J. 324, g913, 18 (June 19). See also Press Release, I.C.J., Speech by H.E. Judge Peter Tomka, President of the International Court of Justice, at the Sixty-fourth Session of the International Law Commission (July 24, 2012).

105 Ahmadou Sadio Diallo (Guinea v. Dem.Rep.Congo), Compensation, 2012 I.C.J. 324, 31 (June 19) (separate opinion of Judge Cançado Trindade). The Court in the Case concerning Application of the Convention on the Prevention and Punishment of the Crime of Genocide made only a passing reference to draft art.31 on State responsibility. In Certain Questions of Mutual Assistance in Criminal Matters and in the Dispute Regarding Navigational and Related Rights Case the Court did not consider draft art.31 on State responsibility. Int'l L. Comm'n, Draft articles on Responsibility of States for Internationally Wrongful Acts with Commentaries, Rep. of the Int'l L. Comm'n (2001), at 91.

106 Ahmadou Sadio Diallo (Guinea v. Dem.Rep.Congo), Preliminary Objections, 2007 I.C.J. 582, 9943, 44, 47 (May 24). The Court relied on the Interhandel Case and on PCIJ's Factory of Chorzow Case. Both the ICJ and the ILC agreed that administrative rules usually do not form part of local remedies requirement. See Int'l L. Comm'n, Draft articles on Diplomatic Protection, with Commentaries, Rep. of the Int'l L. Comm'n (2006), reprinted in [2006] 2 Y.B. Int'l L. Comm'n, U.N.Doc. A/61/10, at 71, 72 (Commentary to draft art.14). Provisional Summary Records of the 2933rd Meeting, [2007] Y.B. Int'l L. Comm'n, U.N.Doc. A/ CN.4/SR.2933. See also Interhandel (Switz. v. U.S.), Preliminary Objections, 1959 I.C.J. 6 (Mar. 9); and Elettronica Sicula S.p.A. (ELSI) (U.S. v. It.), Judgment, 1989 ICJ REP 15 (July 20). The ILC considered draft art.14 to form part of customary international law and relied on Interhandel and the ELSI cases, decisions of European Commission of Human rights and on the United Nations Reports of International Arbitral Awards. 
confirming and complementing the ILC's conclusion. ${ }^{107}$ The ILC Commentary to the draft art.45 on State responsibly stated that waivers should be 'unequivocally implied' in order to denunciate its claims or rights and referred to the decisions in Certain Phosphate Lands in Nauru. ${ }^{108}$ However, the Court also relied on the Certain Phosphate Lands in Nauru decision, and referred to the ILC draft articles only in passim, perhaps because the ILC position was only "similar" and not completely in line with the Court's understanding in relation to waivers. ${ }^{109}$

On some occasions the Court cited to ILC Commentary without referring to the ILC draft articles. In Ahmadou Saido Diallo Case, for example, the Court relied only on the ILC Commentary without citing the draft article itself in establishing the test for the loss of professional remuneration. ${ }^{110}$ In its Commentary, the ILC relied on PCIJ's Factory on Chorzow Case and ICJ's Corfu Channel Case - the same cases the Court also invoked in its Ahmadou Sadio Diallo Case, alongside the ILC Commentary to draft art.36 on State responsibility. ${ }^{111}$

\section{The ICJ Modifies the ILC's Work}

The ICJ does not follow any specific rules of interpretation when interpreting ILC's work. After the Court 'elevates' or 'transplants' the ILC work into customary international law, the ICJ remodels, expands, or narrows the scope of the

107 Armed Activities on the Territory of the Congo (Dem. Rep. of the Congo v. Uganda), Judgment, 2005 I.C.J. 168, 293 (Dec. 19).

108 The ILC refers only to 'unequivocally implied' waivers or renunciations of claims or rights, and does not mention express waivers. Int'l L. Comm'n, Draft articles on Responsibility of States for Internationally Wrongful Acts with Commentaries, Rep. of the Int'l L. Comm'n (2001), at 122. Certain Phosphate Lands in Nauru (Nauru v. Austl.), Preliminary Objections, 1992 I.C.J. 240, 13 (June 26).

109 "Similarly, the International Law Commission, in its commentary on Article 45 of the Draft Articles on Responsibility of States for internationally wrongful acts, points out that "[a]lthough it may be possible to infer a waiver from the conduct of the States concerned or from a unilateral statement, the conduct or statement must be unequivocal'"' Id. See also Int'l L. Comm'n, Draft articles on Responsibility of States for Internationally Wrongful Acts with Commentaries, Rep. of the Int'l L. Comm'n (2001), at 308.

110 Press Release, I.C.J., Speech by H.E. Judge Peter Tomka, President of the International Court of Justice, at the Sixty-fourth Session of the International Law Commission (July 24, 2012). Ahmadou Sadio Diallo (Guinea v. Dem.Rep.Congo), Compensation, 2012 I.C.J. 324, 49 (June 19). See also Press Release, I.C.J., Speech by H.E. Judge Peter Tomka, President of the International Court of Justice, at the Sixty-fourth Session of the International Law Commission (July 24, 2012).

111 Int'1 L. Comm'n, Draft articles on Responsibility of States for Internationally Wrongful Acts with Commentaries, Rep. of the Int'l L. Comm'n (2001), at 99, 100. “The Court used the wording of the Chorzow Factory case, which had been reproduced in the Commentary to the articles of State responsibility..." Press Release, I.C.J., Speech by H.E. Judge Peter Tomka, President of the International Court of Justice, at the Sixty-fourth Session of the International Law Commission (July 24, 2012). 
ILC draft articles, and usually omits the connection to the ILC once the Court has declared a draft article to be reflective of customary international law. ${ }^{112}$

The Court changes and modifies ILC's draft articles according to its own understanding of the applicable rules of international law. Only the Court's interpretation of ILC's draft articles, however, clarifies what the applicable international law is. Therefore, after the Court incorporates the norm into the area of (customary) international law, the Court omits the reference to the ILC altogether.

The Court analyses ILC's work provision-by-provision, usually not considering the complete set of draft articles in determining whether the conclusions reached by the ILC were an accurate reflection of international law. ${ }^{113}$

Although the Court consider ILC's work to be evidence of customary international law, the Court examines on its own whether a particular norm has a customary status. ${ }^{114}$ For example, the Court, taking into consideration Guinea's pleadings in Ahmadou Sadio Diallo examined the status of draft art.11, para. (b) on Diplomatic protection. The Court found the applicable State practice by analyzing multilateral and bilateral treaties that are binding on both States in the dispute before the Court. The Court, by researching on its own the State practice supporting draft art.11, para(b), reached the conclusion that the provision was not customary international law after all. ${ }^{115}$

112 Peil, supra note 10, at 153-157.

113 The Court uses rule-by-rule approach as established in the North Sea Continental Shelf Case, because draft articles contain both lex lata and de lege ferendae elements. Rachmaran, supra note 14, at 205; also Application of the Interim Accord of 13 September 1995 (Maced. v. Greece), Judgment, 2011 I.C.J. 644, 972 (Dec. 5) (dissenting opinion of Judge ad hoc Roucounas). See also Summary Records of the 2775th Meeting, [2003] Y.B. Int'l L. Comm'n 163, U.N.Doc. A/CN.4/SR.2775; Provisional Summary Records of the 2933rd Meeting, [2007] Y.B. Int'l L. Comm'n, U.N.Doc. A/CN.4/SR.2933; Press Release, I.C.J., Speech by H.E. Judge Rosalyn Higgins, President of the International Court of Justice, at the 59th Session of the International Law Commission (July 10, 2007). Cf. United Nations Documents on the Development and Codification of International Law, Suppl. to 41 Am. J. of Int'l L. 4 (1947), at 47; Jimenez de Arechaga, supra note 11, at 33, 35-36; Tunkin, supra note 24, at 538.

114 The Court re-assesses a norm because the ILC usually does not state whether it considers a provision in its draft articles to be lex lata or lex ferendae. Application of the Interim Accord of 13 September 1995 (Maced. v. Greece), Judgment, 2011 I.C.J. 644, 710 (Dec. 5) (declaration of Judge Bennouna). See also Rachmaran, supra note 14, at 205.

115 Ahmadou Sadio Diallo (Guinea v. Dem.Rep.Congo), Preliminary Objections, 2007 I.C.J. 582, $986-89$ (May 24). Press Release, I.C.J., Speech by H.E. Judge Rosalyn Higgins, President of the International Court of Justice, at the 59th Session of the International Law Commission (July 10, 2007). The ILC did not claim this provision to be customary international law. In drafting the exception for the protection by substitution in the Commentary to draft art.11, it relied on the decision of the Chamber of the Court, State practice, doctrine and three individual opinions to Barcelona Traction Case, all of which 'expressed full support' for the proposal. Int'l L. Comm'n, Draft articles on Diplomatic Protection

\section{(C) Palacký University Olomouc, Czech Republic, 2015. ISSN 1213-8770 (print), ISSN: 2464-6601 (online).}


In its interpretation of international law, the Court is not bound by the ILC's findings and conclusions. ${ }^{116}$ For example, in Maritime Delimitation in the Area between Greenland and Jan Mayen Case, the Court interpreted the notion of 'special circumstances' differently than the ILC envisioned. ${ }^{117}$ Also in GabčikovoNagymaros Project, the Court changed the meaning of the provision in the 1980 Commentary on State responsibility, in relation to the duration of 'peril.'.18

The Court's interpretation 'fills the gap' in international law, and its interpretation can lead to the expansion of specific provisions or the whole set of draft articles drafted by the ILC. ${ }^{119}$ For example, in Jurisdictional Immunities of the State Case, the Court found the 'missing' provision of the United Nations Convention on Jurisdictional Immunities of States and Their Property-the Court declared the rule on State immunity for acta jure imperii during armed conflict to be customary international law by relying on its own jurisprudence. ${ }^{120}$ The ICJ expanded the scope of the ILC draft articles despite ILC's purposeful exclusion of the situation of armed conflict from the scope of its work. ${ }^{121}$

The Court in the Case concerning Avena and Other Mexican Nationals expanded the notion of 'notification' by interpreting notification to be a passive and an active right. ${ }^{122}$ Similarly, the Court in Djibouti v. France extended the

with Commentaries, Rep. of the Int'l L. Comm'n (2006), reprinted in [2006] 2 Y.B. Int'l L. Comm'n, U.N.Doc. A/61/10, at 62-65 (Commentary to the draft art.11, noting State practice, arbitral awards and doctrine support the establishment of such an exception). Ahmadou Sadio Diallo (Guinea v. Dem.Rep.Congo), Preliminary Objections, 2007 I.C.J. 582, 9986-87 (May 24).

116 Cf. Maritime Delimitation in the Area between Greenland and Jan Mayen (Den. v. Nor.), Judgment, 1993 I.C.J. 38, 156 (June 14) (separate opinion of Judge Shahabuddeen).

117 Id., 133 (separate opinion of Judge Shahabuddeen); Id., 89 (separate opinion of Judge Schwebel); Id., 305-306 (separate opinion of Judge Fischer); Id., 88 (separate opinion of Judge Ranjeva).

118 Rep. of the Int'l Law Comm'n, 30th Sess., May 5-July 25, (1980), U.N. Doc. A/CN.4/326; GAOR 32nd Sess., Supp. No.10 (1980), reprinted in [1980] 2 Y.B. Int'l L. Comm'n, U.N.Doc. $\mathrm{A} / 35 / 10$. The ILC emphasized that 'peril' has to be 'imminent' and 'present at the actual time,' but the Court held that 'peril' can also last throughout a longer period of time. Gabčikovo-Nagymaros Project (Hung./Slovk.), Judgment, 1997 I.C.J. 7, 54 (Sept. 25).

119 Jurisdictional Immunities of the State (Germ. v. It.: Greece intervening), Judgment, 2012 I.C.J. 99, 978 (Feb. 3). See also North Sea Continental Shelf (Fed. Rep. Germ./Neth.), Judgment, 1969 I.C.J. 3, $9989-90$ (Feb. 20) (separate opinion of Judge Padilla Nervo). When the Court 'fills the gap' the Court either fills a lacunae in international law or clarifies a nonliquet rule of international law.

120 Jurisdictional Immunities of the State (Germ. v. It.: Greece intervening), Judgment, 2012 I.C.J. 99, 977 (Feb. 3).

121 Id., 69.. Int'l L. Comm'n, Draft Articles on Jurisdictional Immunities of States and Their Property, with Commentaries, Rep. of the Int'l L. Comm'n (1991), reprinted in [1991] 2 Y.B. Int'l L. Comm'n, U.N.Doc. A/46/10, at 45 and 46.

122 Avena and Other Mexican Nationals (Mex. v. U.S.), Judgment, 2004 I.C.J. 12, g986-87 (March 31). Id., 99 (separate opinion of Judge Sepulveda) (explaining that the ICJ in the Avena Case clarified for the third time questions concerning the VCCR. In Avena Case the 
conventional notion of a 'diplomatic agent' of art.1 and 29 of the Vienna Convention on Diplomatic Relations to apply also to the Heads of State. ${ }^{123}$ In the same case, the Court also extended the meaning of 'satisfaction' as stated in draft art.37 on State responsibility. The Court included the declaration of the Court to be another form of satisfaction, although the Commentary to draft art.37 does not mention it. ${ }^{124}$ The Court in the Application of the Convention on the Prevention and Punishment of the Crime of Genocide Case similarly extended the scope of the draft art.16 on State responsibility by linking the draft art.16 on State responsibility to art.III, para.(e) of the Convention on the Prevention and Punishment of the Crime of Genocide and attaching to it the notion of 'complicity.' ${ }^{125}$ By connecting these two articles, the Court effectively expanded the scope of the applicability of this draft article to similar cases in the future. ${ }^{126}$

Court interpreted art.36 of the VCCR more extensively than in the LaGrand Case); Ahmadou Sadio Diallo (Guinea v. Dem.Rep.Congo), Judgment, 2010, I.C.J. 639, 9976, 99-100 (Nov. 30) (separate opinion of Judge Mamupya). See also Summary Records of the 2813rd Meeting, [2004] Y.B. Int'l L. Comm'n 153, U.N. Doc. A/CN.4/SR.2813. Provisional Summary Records of the 3100th Meeting, [2011] Y.B Int'l L. Comm'n, U.N. Doc. A/CN.4/SR.3100.

123 "The Court recalls that the rule of customary international law reflected in Article 29 of the Vienna Convention on Diplomatic Relations while addressed to diplomatic agents, is necessarily applicable to the Heads of State." Certain Questions of Mutual Assistance in Criminal Matters (Djib. v. Fr.), Judgment, 2008 I.C.J. 177, 174 (June 4). See also Press Release, I.C.J., Speech by H.E. Judge Rosalyn Higgins, President of the International Court of Justice, at the Sixtieth Session of the International Law Commission (July 22, 2008). Geigher, supra note 53, at 690-91. The Court expanded the meaning of 'inviolability of diplomatic agents' to include also the Head of State. Neither the VCDR nor the ILC Commentary to the draft art.27 (later art.29 VCDR) referred to the Heads of State in this regard. Certain Questions of Mutual Assistance in Criminal Matters (Djib. v. Fr.), Judgment, 2008 I.C.J. 177, 37 (June 4) (separate opinion of Judge Yusuf); Id., פ9 18, 20 (separate opinion of Judge Skotnikov); Id., $\mathbf{9} 13$ (separate opinion of Judge Koroma). The Court and the individual Judges rely only on the text of VCDR in determining the customary status of art.29 and did not cite any other evidence of its customary status.

124 Id., 204. Declaration of the Court was not considered to be a form of satisfaction by the ILC, although the ILC said the list of forms of satisfaction is not exclusive. Int'l L. Comm'n, Draft articles on Responsibility of States for Internationally Wrongful Acts with Commentaries, Rep. of the Int'l L. Comm'n (2001), at 106.

125 The Commentary to the draft art.16 does not refer to complicity, although complicity is mentioned in other places in the Commentary. Int'l L. Comm'n, Draft articles on Responsibility of States for Internationally Wrongful Acts with Commentaries, Rep. of the Int'l L. Comm'n (2001), e.g., at 53, 61, 64, 65, 67. Cf. Draft art.16 on State responsibility and Art.III, para. (c) of the Convention on the Prevention and Punishment of Genocide, Dec. 9, 1948, 78 U.N.T.S. 277. "The Court sees no reason to make any distinction of substance between "complicity in genocide" within the meaning of article III, paragraph (e) of the convention and the "aid or assistance" of a state in the commissions of the wrongful act by another state within the meaning of the article 16." Application of the Convention on the Prevention and Punishment of the Crime of Genocide (Bosn. \& Herz. v. Serb. \& Montenegro), Judgment, 2007 I.C.J. 43, 9419-420 (Feb. 26) (emphasis added).

126 The ICJ relied on the articles also to establish its jurisdiction under the Genocide convention. Id., 48 (dissenting opinion of Judge ad hoc Mahiou); Ahmadou Sadio Diallo 
When interpreting ILC's draft articles, the Court can also narrow their scope. For example, in the North Sea Continental Shelf Case, the Court narrowed the scope of notions adopted by the ILC by equating the terms 'adjacent' and 'equidistant', which the ILC considered separately. ${ }^{127}$ Similarly, Judge Oda in Tunisia/Libya Continental Shelf noted that the Court, by relying solely on the statements by the Special Rapporteur on the topic, effectively narrowed the scope of ILC's work, including the findings of the Committee of Experts. ${ }^{128}$

The Court effectively narrows the effect the ILC draft articles could have had on the States, by simply not invoking ILC's work when the ILC work is otherwise available. ${ }^{129}$ For example, in Ahmadou Sadio Diallo Case the Court deliberately omitted to mention the draft art.11, para.(b) on Diplomatic protection, when deciding whether a rule on protection by substitution exists. ${ }^{130}$ By differentiating the case on the facts, ICJ's holding did not negate the finding of the ILC explicitly. However, the Court's deliberate omission of the ILC's work will influence its application and effect of draft art.11(b) in the future. ${ }^{31}$

(Guinea v. Dem.Rep.Congo), Judgment, 2010, I.C.J. 639, 223 (Nov. 30) (separate opinion of Judge Mampuya).

127 The Court's conclusion was not supported by the travaux préparatoires of the Convention. North Sea Continental Shelf (Fed. Rep. Germ./Neth.), Judgment, 1969 I.C.J. 3, g15 (Feb. 20) (separate opinion of Judge Fouad Ammoun).

128 Continental Shelf (Tunis./Libya), Judgment, 1982 I.C.J. 18, 49 (Feb. 24) (dissenting opinion of Judge Oda).

129 Ahmadou Sadio Diallo (Guinea v. Dem.Rep.Congo), Preliminary Objections, 2007 I.C.J. 582, 991,93 (May 24) (the Court avoided declaring on whether customary international law contains a more limited rule of protection by substitution by finding that the two companies in question were not incorporated in such a way that they would fall in the scope of protection by substitution in the sense of draft art.11, para (b) on Diplomatic protection).

130 Ahmadou Sadio Diallo (Guinea v. Dem.Rep.Congo), Preliminary Objections, 2007 I.C.J. 582, 991 (May 24).

131 Villalpando, supra note 37, at 250. 
ILC draft articles as Legislative History of a Norm, Evidence of Customary International Law, and Evidence of the Development of International Law

While the Court considers that a norm can be interpreted without the ILC's help, ${ }^{132}$ individual Judges consider ILC's work as indicators of the 'normative and substantive value' of a specific norm. ${ }^{133}$

The Court usually considers ILC draft articles and Commentaries to be either evidence of customary international law or a legislative history of an international treaty. ${ }^{134}$ The Court relies on ILC's preparatory work to determine the character and the international legal status of the norm codified in the draft articles or in a treaty provision. ${ }^{135}$

132 Judge Oda agreed with the conclusion of the Court not to consider any more ILC as legislative history, but was not convinced that the Court relied on sufficient evidence when establishing the customary nature of the rule. Maritime Delimitation in the Area between Greenland and Jan Mayen (Den. v. Nor.), Judgment, 1993 I.C.J. 38, g949, 91 (June 14) (separate opinion of Vice-President Oda) (noting the Court did not present any convincing statement of its reasons for having drawn the particular single maritime boundary line and says that by choosing this line rather than any other, the Court seems to have taken a purely arbitrary decision). Judge Schwebel and Judge Ranjeva shared the view of Judge Oda that the Court can determine the nature of the norm without the reference to the ILC. $C f$. Id., at 121-128 (separate opinion of Judge Schwebel); Id., at 87 (separate opinion of Judge Ranjeva) (arguing that while using the margin of discretionary power the Court could employ more specific standards); $I d$., at 288 (separate opinion of Judge Ajibola) (arguing UNCLOS III influenced the "current trend in customary international law"); Id., 313 (separate opinion of Judge Fischer).

133 Judge Shahabuddeen advocated for the Court's reliance on ILC's work in finding an answer to issues, also as determining the importance of a provision, because the ILC is a "commission of jurists, not a committee of technical experts" and therefore the rule has also a normative and substantive value. Judge Shahabuddeen refers to Judge Tanaka's individual opinion and to the Special Rapporteur on the topic and other ILC members who expressed their view on art. 6. Maritime Delimitation between Greenland and Jan Mayen, at 136, $138-40,148,151,182-183$ (separate opinion of Judge Shahabuddeen) (referring to North Sea Continental Shelf Case, at 182-183 (dissenting opinion of Judge Tanaka)). See also Rep. of the Int'l Law Comm'n, 21st Sess., June 2-Aug.8, (1969), U.N. Doc. A/CN.4/220; GAOR 24th Sess. U.N. Doc. A/7610/Rev.1, Supp. No.10 (1969), at 216.

134 Jurisdictional Immunities of the State (Germ. v. It.: Greece intervening), Judgment, 2012 I.C.J. 99, 66 (Feb. 3). North Sea Continental Shelf (Fed. Rep. Germ./Neth.), Judgment, 1969 I.C.J. 3, 15 (Feb. 20) (separate opinion of Judge Ammoun). Danilenko, supra note 25, at 149, 155 (noting that State negotiations, statements of governments and contributions of States at international conferences forming important State practice, which should be considered in treaty interpretation). Kaczotowska, supra note 11, at 29.

135 Villalpando, supra note 37 , at 247. ILC's work should not be automatically considered to be reflective of the opinio juris of the international community. ILC's research is limited to the contributions of Special Rapporteurs, the Secretariat and (some) ILC members. See also Summary Records of the 2585th Meeting, [1999] Y.B. Int'l L. Comm'n 122, U.N.Doc. A/ CN.4/SR.2585. 
ILC draft articles are also evidence of the development of international law. For example, in Gabčikovo-Nagymaros Project Case the ICJ first relied on the PCIJ's Territorial Jurisdiction of the International Commission of the River Oder Case in relation to the question of the community interest in a navigable river. The Court also considered ILC's work, which summarized the development of international law in this area. ${ }^{136}$

ILC's work can also persuade the Court that there are no customary rules on the issue. For example, in North Sea Continental Shelf Case, the Court at the request of Denmark and the Netherlands tried to determine whether art.6 of the 1958 Geneva Convention on the Continental Shelf reached the status of customary international law. ${ }^{137}$ Since the ILC had not mentioned any State practice in the Commentary to art.6 that could inform the Court, the Court relied heavily on the discussion among the ILC members while drafting the provision that later became art. 6 of the Geneva Convention. ${ }^{138}$ The Court took into consideration ILC's hesitation in drafting this rule and ILC's refusal to prioritize this rule in relation to other rules in the treaty in deciding that art.6 had not yet ripened into a rule of customary international law. ${ }^{139}$ However, the Court in Jurisdictional

136 Territorial Jurisdiction of the International Commission of the River Oder, Judgment No. 16, 1929 P.C.I.J., Series A, No. 23 at 27; cited in Gabčikovo-Nagymaros Project (Hung./ Slovk.), Judgment, 1997 I.C.J. 7, 85 (Sept. 25) (referring to 1997 Convention on NonNavigational Uses of International Watercourses as to the 'modern' development of international law).

137 If the Court would find a customary rule, Germany would be bound by that provision, although it had not yet ratified the Convention at the time of the dispute before the ICJ. Maritime Delimitation in the Area between Greenland and Jan Mayen (Den. v. Nor.), Judgment, 1993 I.C.J. 38, 288 (June 14) (separate opinion of Judge Ajibola). See also North Sea Continental Shelf (Fed. Rep. Germ./Neth.), Judgment, 1969 I.C.J. 3, 91 (Feb. 20) (individual opinion of Judge Padilla).

138 North Sea Continental Shelf (Fed. Rep. Germ./Neth.), Judgment, 1969 I.C.J. 3, at 91 (Feb. 20) (separate opinion of Judge Padilla). Judge Padilla explained the Court's determination whether the rule in art.6 is customary international law depended on the quality of ILC's work. The Court also noted the question of equidistance (art.6 of the Geneva Convention on the Continental Shelf) was considered by the Commission only from 1950 to 1953, before it was referred to the Committee of Experts. Id., 9948, 50-53; and Id., 8 (dissenting opinion of Judge Morelli); Id., at 88, 92 (separate opinion of Judge Padilla Nervo); Id., at 221, 226 (individual opinion of Judge Lachs). See also Jimenez de Arechaga, supra note 11 , at $27-28$.

139 North Sea Continental Shelf (Fed. Rep. Germ./Neth.), Judgment, 1969 I.C.J. 3 , 550 (Feb. 20); Id., 175 (individual opinion of Judge Tanaka) (claiming the codification of the rule accelerated its incorporation into customary international law); Rep. of the Int'l Law Comm'n, 5th Sess., June 1-Aug. 8, (1953), U.N. Doc. A/CN.4/76; GAOR 5th Sess., Supp. No.9 (1953), at 216. Maritime Delimitation in the Area between Greenland and Jan Mayen (Den. v. Nor.), Judgment, 1993 I.C.J. 38, 154 (June 14) (separate opinion of Judge Shahabuddeen), Jimenez de Arechaga, supra note 11, at 34. See also Danilenko, supra note 25, at $143-146,152$. The Court found that art.6 was not reflective of customary international law at the time when it was drafted and had not yet obtained that status at the time when the Court considered it. North Sea Continental Shelf (Fed. Rep. Germ./Neth.), Judgment, 
Immunities of the State Case declared art.6 of United Nations Convention on Jurisdictional Immunities of States and Their Property, drafted by the ILC, to be customary international law, despite the disagreement among the ILC members in 1980 , when they were deciding whether art. 6 is a customary rule. ${ }^{140}$

ILC's work is from the Court's point of view the legislative history of a norm. ILC's travaux préparatoires guide the Court in finding the nature of the norm and in clarifying the meaning of a particular ILC provision. ${ }^{141}$ The ICJ does not consider ILC's work as legislative history when States changed the draft articles while adopting a treaty or when the Court already interpreted the specific provision. ${ }^{142}$ For example, when deciding on the customary status of particular provisions of the Vienna Convention on Diplomatic Relations and the Vienna Convention on Consular Relations (both drafted by the ILC) in United States Diplomatic and Consular Staff in Tehran Case the Court considered as a travaux préparatoires only the 1961 codification conference, and not the ILC work on the topic. ${ }^{143}$ The ICJ also refrained from considering ILC's work as the legislative history of the

1969 I.C.J. 3, 9950, 60-62, 69 (Feb. 20). See also Schwebel, supra note 21, at 162-163; Geigher, supra note 53, at 689. Cf. Rep. of the Int'l Law Comm'n, 65th Sess., May 6-June 7, July 8-Aug.9, (2013), U.N. Doc.A/CN.4/656; GAOR 68th Sess., Supp. No. 10 (2013), reprinted in [2013] Y.B. Int'l L. Comm'n, U.N.Doc. A/68/10.

140 Rep. of the Int'l Law Comm'n, 30th Sess., May 5-July 25, (1980), U.N. Doc. A/CN.4/326; GAOR 32th Sess., Supp. No.10 (1980), at 142. Current and modified version is art.5 of United Nations Convention on Jurisdictional Immunities of States and Their Property, Dec.2, 2004, U.N. Doc. A/59/508. Jurisdictional Immunities of the State (Germ. v. It.: Greece intervening), Judgment, 2012 I.C.J. 99, 56 (Feb. 3). See also Int'l L. Comm'n, Draft articles on Jurisdictional Immunities of States and Their Property, with Commentaries, Rep. of the Int'l L. Comm'n (1991), reprinted in [1991] 2 Y.B. Int'l L. Comm'n, U.N.Doc. $\mathrm{A} / 46 / 10$.

141 Continental Shelf (Tunis./Libya), Judgment, 1982 I.C.J. 18, 41 (Feb. 24); Ahmadou Sadio Diallo (Guinea v. Dem.Rep.Congo), Judgment, 2010, I.C.J. 639, gg18, 20 (Nov. 30) (separate opinion of Judge Mampuya). See also Rep. of the Int'l Law Comm'n, 16th Sess., May 11-July 24, (1964), U.N. Doc. A/CN.4/173; GAOR 19th Sess., Supp. No.9 (1964), at 58.

142 Jimenez de Arechaga, supra note 11, at 36-37 (noting that the preparatory work of codification conferences can be used for interpretation of the text of the treaty and for determination of the consensus of States; referring to Delimitation Maritime Boundary in the Gulf of Maine Area Case). See also e.g. Jurisdictional Immunities of the State (Germ. v. It.: Greece intervening), Judgment, 2012 I.C.J. 99, 68 (Feb. 3) (considering statements made by States in the Sixth committee, along the comments on the work of the ILC). GabčikovoNagymaros Project (Hung./Slovk.), Judgment, 1997 I.C.J. 7, 124 (Sept. 25). The Court gives precedence to the statements of States and usually does not consider ILC's travaux préparatoires. Therefore, the Court would more likely than not omit to consider ILC's travaux préparatoires when States changed the draft at the codification conference. See also LaGrand (Ger. v. U.S.), Judgment, 2001 I.C.J. 466, 8 (June 27) (dissenting opinion of Judge Shi); Memorial of the United States, United States Diplomatic and Consular Staff in Tehran, (U.S. v. Iran), Pleadings, 1979 I.C.J., g999-100 (May 24).

143 United States Diplomatic and Consular Staff in Tehran (U.S. v. Iran), Judgment, 1980 I.C.J. 3, 47 (May 24). The Court did not refer to the ILC's work, as the United States suggested in their pleadings. Id., 94 . 
Vienna Convention on Consular Relations in the Avena Case. ${ }^{144}$ In interpreting the Vienna Convention on Consular Relations in Ahmadou Sadio Diallo Case, the Court referred only to the Avena Case, without considering ILC's contribution in drafting the treaty.

The Court usually invokes ILC's travaux préparatoires when it relies on a particular provision for the first time. In all subsequent decisions that interpret the same provision, the Court refers to its own jurisprudence, sometimes also omitting to mention also the debates at the codification conferences. Examples of this approach are in the Court's interpretation of art.29 Vienna Convention on Diplomatic Relations in the United States Diplomatic and Consular Staff in Tehran Case, in Armed Activities on the Territory of the Congo Case, and in Certain Questions of Mutual Assistance in Criminal Matters Case. In these cases the Court did not invoke ILC's preparatory work to art.29 of Vienna Convention on Diplomatic Relations. ${ }^{145}$ The Court in the United States Diplomatic and Consular Staff in Tehran Case relied on conclusions reached at the codification conference, but in the subsequent Armed Activities on the Territory of the Congo Case, the Court omitted the reference to the codification conference. The Court also interpreted art.29 Vienna Convention on Diplomatic Relations in Certain Questions of Mutual Assistance in Criminal Matters Case. The Court relied only on the text of the treaty without mentioning the preparatory work leading up to art.29. ${ }^{146}$

144 Ahmadou Sadio Diallo (Guinea v. Dem.Rep.Congo), Judgment, 2010, I.C.J. 639, 995 (Nov. 30); Avena and Other Mexican Nationals (Mex. v. U.S.), Judgment, 2004 I.C.J. 12, g980, 86 (March 31). The text of the VCCR contained no definition of 'without undue delay.' The Court decided that 'without undue delay' can also be interpreted as 'immediately upon arrest.' The ICJ cited in its decision only comments made by States at the codification conference and to the opinion of the Special Rapporteur on the topic, but omitted the reference to the commentary of the ILC, although the ILC had discussed this issue at length. See also Summary Records of the 2813rd Meeting, [2004] Y.B. Int'l L. Comm'n 153, U.N.Doc. A/CN.4/SR.2813 and Int'l L. Comm'n, Draft Articles on Consular Relations, with Commentaries, Rep. of the Int'l L. Comm'n (1961), reprinted in [1961] 2 Y.B. Int'l L. Comm'n, U.N.Doc. A/CN.4/141, at 113. The Court justified the deviation from the ILC work by stating that the parties to the dispute disagreed on the scope of the obligation in relation to art.36 of the VCCR in para.153(9) of the Avena judgment. Press Release, I.C.J., Speech by H.E. Judge Rosalyn Higgins, President of the International Court of Justice, at the Sixtieth Session of the International Law Commission (July 22, 2008). In the subsequent case on the Reinterpretation of Avena judgment the Court did not rely neither on the ILC work or States' preparatory work at the codification conference in relation to art.36 VCCR. See also Request for Interpretation of the Judgment of 31 March 2004 in the Case concerning Avena and Other Mexican Nationals (Mexico v. United States of America) (Mex. v. U.S.), Judgment, 2009 I.C.J. 3, 9963-64 (Jan. 19) (separate opinion of Judge Sepulveda).

145 Armed Activities on the Territory of the Congo (Dem. Rep. of the Congo v. Uganda), Judgment, 2005 I.C.J. 168, 9937, 340 (Dec. 19).

146 Certain Questions of Mutual Assistance in Criminal Matters (Djib. v. Fr.), Judgment, 2008 I.C.J. 177, 163 (June 4) (noting art.29 VCDR does not encompass the Heads of States under the term 'diplomatic staff'). Vienna Convention on Diplomatic Relations, Apr. 18, 1961, 500 U.N.T.S. 95. 
ILC's Commentaries on draft articles re-interpreted and modified either by States or by the ICJ lose their significance in subsequent interpretation attempts. ILC's draft articles are interpreted in the light of the ICJ's jurisprudence and the applicable international law.

The Court also omits reference to ILC's work when it determines that an ILC draft article is customary international law. For example, in interpreting art.6 of the Geneva Convention on the Continental Shelf, the Court noted many disagreements within the ILC while drafting art.6, ${ }^{147}$ and the Court in several cases did not consistently rely on ILC's preparatory work, nor the amendments made by States at the codification conferences. Instead, while interpreting art.6, the Court relied predominately on its previous jurisprudence. ${ }^{148}$

When the Court first considered art.6 in the North Sea Continental Shelf Case in 1969, the Court declared that art.6 has not yet reached the customary status. After 24 years and six ICJ decisions, the Court decided that this rule had transitioned into the body of customary international law. ${ }^{149}$ In one of the cases where

147 Art. 6 corresponds to art.12 of the Geneva Convention on the Territorial Sea. Geneva Convection on the Continental Shelf, art.6, Apr.29, 1958, 499 U.N.T.S. 311; and Geneva Convention on the Territorial Sea, art.12, Apr.29, 1958, 516 U.N.T.S. 205.

148 The Court refers to the ILC's preparatory work only while considering a relevant provision for the first time. In subsequent considerations of the preparatory work the Court usually omits the reference to the ILC. For example, the Court in 1969 North Sea Continental Shelf Case the Court considered art.6 of the Geneva Convention only in the light of the ILC work; in the 1984 Delimitation of the Maritime Boundary in the Gulf of Maine Area Case the Chamber considered its own jurisprudence alongside ILC's preparatory work. Delimitation of the Maritime Boundary in the Gulf of Maine Area (Can./U.S.), Judgment, 1984 I.C.J. 246, 91 (Jan. 20) (citing North Sea Continental Shelf Case, at 85). In 1993 Maritime Delimitation between Greenland and Jan Mayen Case the Court noted that concept of 'relevant circumstances' to be take into consideration in delimitation was developed through the jurisprudence of the courts, arbitral tribunals and UNCLOS conference. Maritime Delimitation in the Area between Greenland and Jan Mayen (Den. v. Nor.), Judgment, 1993 I.C.J. 38, at 62 (June 14).

149 The Court in North Sea Continental Shelf Case concluded art.6 is not customary international law (also) due to the hesitation of the ILC while drafting the provision. The Court considered the nature of art.6 again in the Maritime Boundary in the Gulf of Maine Area Case, and reaffirmed that this rule was not customary international law (despite some subsequent State practice regarding the equidistance rule following the adoption of the 1958 Geneva Convention and the newly drafted provisions in the 1982 United Nations Convention on the Law of the Sea). The Court considered art.6 also in the Libya/Malta Continental Shelf Case, Maritime Delimitation and Territorial Questions between Qatar and Bahrain Case, Land and Maritime Boundary between Cameroon and Nigeria Case and in the Case Concerning Territorial and Maritime Dispute Between Nicaragua and Honduras in the Caribbean Sea, but the rule has still not attained the status of customary international law. Finally, in the case of Maritime Delimitation between Greenland and Jan Mayen in 1993 the Court considered the notion of 'special circumstances' of art.6 of the 1958 of Geneva Convention and the Court confirmed the rule's customary status. By 2006 art. 6 became "the preferred method of delimitation of the exclusive economic zone and continental shelf as well as for territorial seas." Press Release, I.C.J., Speech by H.E. Judge Rosalyn Higgins, 
art.6 of the Geneva Convention on the Continental Shelf was considered, the Court did not refer either to State practice or to the ILC work, but mentioned only the debate at the codification conference. ${ }^{150}$ Also in the Case Concerning Territorial and Maritime Dispute Between Nicaragua and Honduras in the Caribbean Sea, where the applicable law was art.15 of UNCLOS III, the Court first relied on its jurisprudence and only later turned to ILC's drafting history of art.12 Geneva Convention on Territorial Sea, which corresponds to art.6 of the Geneva Convention on the Continental Shelf. ${ }^{151}$

Similarly, the Court considered the legislative history of the draft art.4 on State responsibility in the Advisory Opinion on Difference Relating to Immunity from Legal Process of a Special Rapporteur of the Commission on Human Rights and in the Application of the Convention on the Prevention and Punishment of the Crime of Genocide Case. In the Advisory Opinion on Difference Relating to Immunity from Legal Process of a Special Rapporteur of the Commission on Human Rights the Court declared draft art.4 on State responsibility to be customary international law. ${ }^{152}$ Because the Court declared art. 4 on State responsibility to

President of the International Court of Justice, at the Sixtieth Session of the International Law Commission (July 22, 2008). See also Geigher, supra note 53, at 389.

150 Maritime Delimitation in the Area between Greenland and Jan Mayen (Den. v. Nor.), Judgment, 1993 I.C.J. 38, 55 (mentioning the debate at the First United Nations Conference on the Law of the Sea in relation to the definition concept of special circumstances).

151 Art.15 of United Nations Convention on the Law of the Sea corresponds to art.12 of the Geneva Convention on the Territorial Sea and the Contiguous Zone. Territorial and Maritime Dispute Between Nicaragua and Honduras in the Caribbean Sea (Nicar. v. Hond.), Judgment, 2007 I.C.J. 659, 280 (Oct. 8) (noting that art.15 was adopted only with minor editorial changes and the provisions in the Geneva Convention and United Nations Convention on the Law of the Sea were 'virtually identical'). In the Case Concerning Territorial and Maritime Dispute Between Nicaragua and Honduras in the Caribbean Sea the Court referred to the North Sea Continental Shelf Case. "The jurisprudence of the Court sets out the reasons why the equidistance method is widely used in the practice of maritime delimitation ..." Id., g272. The ICJ referred to the 1952 Commentary, before the matter was referred to the Committee of Experts. The Commentary did not change when the ILC concluded the topic in 1956. Id., 280 (citing Rep. of the Int'l Law Comm'n, 4th Sess., June 4-Aug.8, (1952), U.N. Doc. A/CN.4/58 \& Corr.1; GAOR 8th Sess., Supp. No.9 U.N.Doc. A/2456 (1952), at 38 (the Court finding that 'special circumstance' precluded the use of the equidistance principle). See also Rep. of the Int'l Law Comm'n, 8th Sess., Apr. 23-July 4, (1956), U.N. Doc. A/CN.4/104 and Corr.1; GAOR 11th Sess., Supp. No.9 (1956), at 271-272, 284 and 300. See also Maritime Delimitation and Territorial Questions between Qatar and Bahrain (Qatar v. Bahr.), Judgment, 2001 I.C.J. 40, 176 (Mar. 16) and Land and Maritime Boundary between Cameroon and Nigeria (Cameroon v. Nigeria: Eq. Guinea intervening), Judgment, 2002 I.C.J. 303, 288 (Oct. 10). The Court confirmed the position of the equidistance rule, because it used it in other judgments. Press Release, I.C.J., Speech by H.E. Judge Rosalyn Higgins, President of the International Court of Justice, at the Sixtieth Session of the International Law Commission (July 22, 2008).

152 Interestingly, the Court declared draft art.4 to be customary international law, without citing to any authority or any precedent, and relying solely on the Commentary to the draft art.4. Difference Relating to Immunity from Legal Process of a Special Rapporteur of the 
reflect customary international law, the reference to the ILC-the 'legislator' of draft art.4-was 'vanished' from the Court's subsequent decision in the Application of the Convention on the Prevention and Punishment of the Crime of Genocide Case. ${ }^{153}$

\section{Reversed International Law-Making? Disagreements in Interpreting International Law}

The Court decides propio motu whether it will rely on ILC's work in finding the applicable international law. ${ }^{154}$ Although the ICJ considers the issue relates to the same question of international law the ILC has previously codified, the ICJ sometimes decides not to refer to it. ${ }^{155}$ The Court does not disclose the reasons why it sometimes refrains from using the work of the ILC. ${ }^{156}$ For example, in Costa Rica v. Nicaragua both parties to the dispute invoked ILC draft art.30 on

Commission on Human Rights, Advisory Opinion, 1999 I.C.J. 62, 9962, 63 (Apr. 29). The ILC was certain that the provision reflected the current state of international law. See Rep. of the Int'l Law Comm'n, 25th Sess., (1973), U.N. Doc. A/9010/REV.1; GAOR 28th Sess., Supp. No.10 (1973), reprinted in [1973] 2 Y.B. Int'l L. Comm'n, U.N.Doc. A/2163, at 198. A similar approach was taken also in Belgium v. Senegal Case: "The Court observes that, under Article 27 of the Vienna Convention on the Law of Treaties, which reflects customary law." Questions Relating to the Obligation to Prosecute or Extradite (Belg. v. Sen.), 2012 I.C.J. 422, g113 (July 20).

153 Difference Relating to Immunity from Legal Process of a Special Rapporteur of the Commission on Human Rights, Advisory Opinion, 1999 I.C.J. 62, 62 (Apr. 29); see GabčikovoNagymaros Project (Hung./Slovk.), Judgment, 1997 I.C.J. 7, g83 (Sept. 25) (the Court referring to art.50 on State responsibility). See also Rep. of the Int'l Law Comm'n, 25th Sess., (1973), U.N. Doc. A/9010/REV.1; GAOR 28th Sess., Supp. No.10 (1973), reprinted in [1973] 2 Y.B. Int'l L. Comm'n, U.N.Doc. A/2163, at 193. Summary Records of the 2775th Meeting, [2003] Y.B. Int'l L. Comm'n 163, U.N.Doc. A/CN.4/SR.2775.

154 "[W]hile the Court may order, as it has done in the past, a State responsible for internationally wrongful conduct to provide the injured State with assurances and guarantees of non-repetition, it [will rely on the ILC work] only if the circumstances so warrant, which it is for the Court to assess." Dispute regarding Navigational and Related Rights (Costa Rica v. Nicar.), Judgment, 2009 I.C.J. 213, 9150 (July 13).

155 The Court decides not to refer to the ILC for various reasons. If, for example, ILC's work is not of a satisfactory quality, ILC's work does not address the same issue the Court considers, the ILC draft articles are not reflective of international customary international law, etc.. An interesting example is the Court's reasoning in the Application of the Genocide Convention Case. The Court in this case declared draft art.16 on State Responsibility to be customary international law-although this draft article was not essential to the resolution of the issue at hand. The Court however refrained from invoking those draft articles on which States relied on in their submissions before the Court. Application of the Convention on the Prevention and Punishment of the Crime of Genocide (Bosn. \& Herz. v. Serb. \& Montenegro), Judgment, 2007 I.C.J. 43, 420 (Feb. 26).

156 Summary Records of the 2698st Meeting, [2001] Y.B. Int'l L. Comm'n 208, U.N.Doc. A/ CN.4/SR.2698. 
State responsibility. The Court relied on the content of the draft art.30 on State responsibility, but it did not refer to the draft art.30 in its decision. ${ }^{157}$

Usually, the Court decides not to refer to ILC's work when it disagrees with the conclusions reached by the ILC or when the ILC misinterpreted the ICJ jurisprudence. Consequently, when the Court omits any reference to the ILC draft articles, ILC's work does not become as authoritative as it would be, if the Court had referred to it in the ICJ decision. ${ }^{158}$ The Court's interpretation of the applicable international law prevails over the ILC's findings.

For example, the Court in Ahmadou Sadio Diallo Case held that the ILC misinterpreted the dictum in Court's decision in Barcelona Traction Case on the issue of protection by substitution. ${ }^{159}$ The ILC in drafting art.11, para.(b) on Diplomatic protection chose to 'fill the gap' the Court left in relation to possible exceptions. The Court re-interpreted its dictum in Barcelona Traction Case rather than relying on the ILC conclusion, and decided that the exception, codified in draft art.11(b) on Diplomatic protection, did not form part of international (customary) law.

\section{The Court Declines to Consider ILC's Work}

Few instances display disagreement between the ICJ and the ILC in interpreting the applicable international law. The very first time the Court had the opportunity to rely on ILC's work, it refused to do so, because it disagreed with the conclusions reached by the ILC. In the 1951 Advisory Opinion on the Res-

157 Costa Rica relied on the draft art.30, para.b and art.37, while Nicaragua invoked the Commentary to draft art.18, and draft art.31, para.2, art.30, para.b and art.22 of the $1977 \mathrm{draft}$ articles on State responsibility. The Court instead of relying on draft art.30, based the obligation to cease with the wrongful act on the State's obligation to comply with the Court Judgment encompassed in art.59 Statute of the International Court of Justice (basing its decision on the presumption of good faith. Dispute Regarding Navigational and Related Rights (Costa Rica v. Nicar.), Judgment, 2009 I.C.J. 213, g 148, 150 (July 13). Press Release, I.C.J., Speech by H.E. Judge Peter Tomka, President of the International Court of Justice, at the Sixty-fourth Session of the International Law Commission (July 24, 2012) (noting that it was not necessary always to refer to the number of the article, but rather on its substance).

158 Cf. Villalpando, supra note 37, at 247, 249-251. Avena and Other Mexican Nationals (Mex. v. U.S.), Judgment, 2004 I.C.J. 12, 13 (March 31) (separate opinion of Judge Vereshchetin).

159 Ahmadou Sadio Diallo (Guinea v. Dem.Rep.Congo), Preliminary Objections, 2007 I.C.J. 582, 9986-90 (May 24) (noting that the Court had not had the chance to clarify the issue raised in the Barcelona Traction Case on the exception to diplomatic protection of shareholders of protection by substitution, and finding that that exception, as proposed by Guinea by relying on ILC's work, did not yet form part of customary international law. Id., 634, 635 (separate opinion of Judge Mampuya) (explaining that the Court relied on the ELSI Case but did not rely on the ILC's draft art.11, para.(b) because the ILC misinterpreted the ELSI Case in drafting that provision and suggesting the Court should have examined the exception drafted by the ILC); Id., at 623, 624 (declaration of Judge ad hoc Mahiou) (arguing for the assessment of the ILC draft art.11). 
ervations to the Convention on the Prevention and Punishment of the Crime of Genocide the Court did not agree with the conclusions reached by the ILC, based on the survey of State practice, that all parties to the convention have to agree before the reservation has an effect. The Court in its advisory opinion decided to adopt a more practical solution, and determined that States can make reservations to treaties without the consent of all parties to the convention. ${ }^{160}$ ICJ's decision was not reflective of the then-current State practice; however, it generated new State practice. The ICJ's decision and its influence on State practice resulted in ILC adopting the Court's view in 1962 and revising its draft articles on the law of treaties. ${ }^{161}$

Half a century after the Advisory Opinion on the Reservations to the Convention on the Prevention and Punishment of the Crime of Genocide, the ICJ's and the ILC's view on the validity of draft art.30 on State responsibility on non-repetition resulted in another public disagreement between the bodies. ${ }^{162}$ In deciding the LaGrand Case the Court stated its position regarding non-repetition while the ILC was still in the process of drafting art.30 on State responsibility on nonrepetition. ${ }^{163}$ Unlike in the 1951 when the ICJ issued its decision after the ILC

160 "The opinion of the Court is an important instance of a judicial attempt to lay down a new legal regime in the face of what the court considered to be the absence of a binding customary international law on the subject and to that extent it may be properly regarded as an instance of judicial legislation." Lauterpacht, supra note 10, at 187 and 190 (analyzing the Court's findings in the 1951 Advisory Opinion on the Reservations to the Genocide Convention; noting the Court's opinion was unorthodox and apparently inconclusive, but an important contribution to the law of treaties). First Rep. on the Law of Treaties (1962), at 73 et seqq. (analyzing the Court's findings and noting the Court extended its mandate on the reservations beyond the Convention on the Prevention and Punishment of the Crime of Genocide). See also Schwebel, supra note 3, at 408. "The Court at least provided a solution capable of general application." Lauterpacht, $I d$., at 189.

161 Schwebel, supra note 3, at 411 . The Secretary-General who, as the depositary of multilateral conventions, adopted the approach established by the ICJ. Neither the General Assemby, nor the States, did endorse the ILC's proposal. The States have been relying on the more flexible approach established with the Genocide Convention. Although the ILC considered this topic in 1953 and in 1956, it adopted the proposal made by Sir Humprey Waldock, who brought the ILC's work in line with the ICJ's findings, in adopting the draft articles on the law of treaties in 1968. Int'l L. Comm'n, Draft Articles on the Law of Treaties, with Commentaries, Rep. of the Int'l L. Comm'n (1966), reprinted in [1966] 2 Y.B. Int'l L. Comm'n, U.N.Doc. A/CN.4/191, also First Rep. on the Law of Treaties (1962), at 73 et seqq.

162 Peter Tomka, Statement of the Chairman of the Drafting Committee, State Responsibility for International Wrongful Acts (Aug. 3, 2001); Summary Records of the 2698st Meeting, [2001] Y.B. Int'l L. Comm'n 208, U.N.Doc. A/CN.4/SR.2698.

163 Summary Records of the 2698st Meeting, [2001] Y.B. Int'l L. Comm'n 208, U.N.Doc. A/ CN.4/SR.2698. The decision in LaGand Case and the draft articles on State responsibility were adopted in the same year. LaGrand Case was decided on July 27, 2001, while ILC held its annual session and was drafting this provision. LaGrand (Ger. v. U.S.), Judgment, 2001 I.C.J. 466 (June 27); Rep. of the Int'l Law Comm'n, 52th Sess., Apr.23-June 1 \& July 2-Aug.10, (2001), U.N. Doc. A/CN.4/521 and Corr.1; GAOR 53th Sess., Supp. No.9 (2001), reprinted in [2001] 2 Y.B. Int'l L. Comm'n, U.N.Doc. A/56/10. Instances of 'simultaneous' 
submitted its research to the General Assembly, the ILC considered the issue of non-repetition after the ICJ issued its decision in LaGrand Case. The Court found that non-repetition is a component of satisfaction. ${ }^{164}$ The ILC partially disagreed with this conclusion and found that non-repetition could be, but it is not always, a component of satisfaction. ${ }^{165}$ The ILC reproduced the LaGrand Case in its Commentary to draft art.30 on State responsibility, but stated that ICJ's position was not the only authority on which the ILC based its decision on assurances and guarantees of non-repetition. ${ }^{166}$

When ICJ disagrees with the conclusions reached by the ILC, it relies only on its own findings and jurisprudence, while disregarding the ILC's position. ${ }^{167}$ For example, in Maritime Delimitation in the Black Sea, the Court relied on its own case-law and it omitted any reference to the ILC's Guiding Principles Applicable to Unilateral Declarations. ${ }^{168}$ The Court held that Romania's unilateral declaration had no legal weight on the Court's interpretation, despite ILC's suggestions

consideration of the same issue by the Court and the ILC are rare.

164 The ILC did not take the final position on the matter until decision in LaGrand Case was rendered. Summary Records of the 2698st Meeting, [2001] Y.B. Int'l L. Comm'n 208, U.N.Doc. A/CN.4/SR.2698.

165 The ILC drafting Committee stated draft art.38 on satisfaction should indicate that sometimes such assurances and guarantees could be provided as a form of the remedy of satisfaction. Peter Tomka, Statement of the Chairman of the Drafting Committee, State Responsibility for International Wrongful Acts (Aug. 3, 2001). See also Summary Records of the 2698st Meeting, [2001] Y.B. Int'l L. Comm'n 208, U.N. Doc. A/CN.4/SR.2698.

166 The ILC claimed the Court did not take a clear position on the matter. The ILC Drafting Committee was of the opinion the Court had not taken a clear position on the obligation to provide assurances and guarantees of non-repetition. The Drafting Committee decided to keep article 30 (b) and article 48 , para.2(a) because they were drafted with flexibility and they introduced a useful policy. Peter Tomka, Statement of the Chairman of the Drafting Committee, State Responsibility for International Wrongful Acts (Aug. 3, 2001). As the ICJ does not have a uniform approach in considering ILC's work, also the ILC does not have a uniform approach towards the jurisprudence of the Court. See also Summary Records of the 2698st Meeting, [2001] Y.B. Int'l L. Comm'n 208, U.N. Doc. A/CN.4/SR.2698. Int'l L. Comm'n, Draft articles on Responsibility of States for Internationally Wrongful Acts with Commentaries, Rep. of the Int'l L. Comm'n (2001), reprinted in [2001] 2 Y.B. Int'l L. Comm'n, U.N.Doc. A/56/10 \& Corr.1, at 90 (Commentary to draft art.30). The ILC Drafting Committee recognized the importance of the ICJ decision, but said ICJ decisions were not the only basis on which the ILC should decide regarding assurances and guarantees of non-repetition.

167 The Court, for example, did not distinguish between acta jure gestiones and acta jurie imperii, whereas the ILC did not intend to restrict art.12 of the United Nations Convention only to acta jure gestionis. Press Release, I.C.J., Speech by H.E. Judge Peter Tomka, President of the International Court of Justice, at the Sixty-fourth Session of the International Law Commission (July 24, 2012); Jurisdictional Immunities of the State (Germ. v. It.: Greece intervening), Judgment, 2012 I.C.J. 99, 64 (Feb. 3).

168 The Court interpreted and applied the provision of UNCLOS III in accordance with its case-law and art.31 of VLCT. Maritime Delimitation in the Black Sea (Rom. v. Ukr.), Judgment, 2009 I.C.J. 61, 42 (Feb. 3). 
in its Guiding Principles that such unilateral declarations should create legal obligations. ${ }^{169}$

The Court in the Case concerning Avena and Other Mexican Nationals could have referred to the draft articles on State responsibility and to the unfinished draft articles on Diplomatic protection, but the Court did not invoke them in its reasoning. ${ }^{170}$ In another instance-in the Advisory Opinion on the Legal Consequences of the Construction of a Wall in the Occupied Palestinian Territory-the Court did not rely on draft art.40 and art.41 on State responsibility and invoked instead art.1 of the Fourth Geneva Convention of 1949. ${ }^{171}$ The Court also decided not to rely on ILC's work in Certain Questions of Mutual Assistance in Criminal Matters Case, ${ }^{172}$ in the Application of the Interim Accord of 13 September 1995 Case, and in the Pulp Mills on the River Uruguay Case. ${ }^{173}$ In the latter case, Uru-

169 Guiding Principles Applicable to Unilateral Declarations of States Capable of Creating Legal Obligations with Commentaries Thereto, Rep. of the Int'l L. Comm'n (2006), reprinted in [2006] 2 Y.B. Int'l L. Comm'n, U.N.Doc. A/61/10.

170 All four judges in their separate opinions to Avena invoked the work of the ILC either on diplomatic protection or State responsibility, or both. Avena and Other Mexican Nationals (Mex. v. U.S.), Judgment, 2004 I.C.J. 12, g929, 31, 71, 77, 79, 80 (March 31) (separate opinion of Judge ad hoc Sepulveda); Id., 10 (separate opinion of Judge Tomka); Id., g925, 28 (separate opinion of Judge Parra-Aranguren); Id., 4 (separate opinion of Judge Vereshchetin); Summary Records of the 2813rd Meeting, [2004] Y.B. Int'l L. Comm'n 153, U.N.Doc. A/CN.4/SR.2813 (the President of the ICJ noting that ICJ did not consider the ILC draft articles on diplomatic protection because local remedies were not exhausted).

171 Reliance on the Geneva Conventions enabled the Court to afford reparation to natural and legal persons and not only to the States, as the ILC had envisioned. Legal Consequences of the Construction of a Wall in the Occupied Palestinian Territory, Advisory Opinion, 2004 I.C.J. 136, 144 (July 9). Individual Judges advocated for consideration of the ILC draft articles. Id., 4 (declaration of Judge Buergenthal); Id., 37 (separate opinion of Judge Higgins); Id., 40 (separate opinion of Judge Kooijmans); Villalpando, supra note 37, at 250, fn. 41.

172 The Court found that France did not comply with the Treaty on Mutual Assistance and declared that the mere finding of violation constituted a satisfaction. Summary of the Judgment of June 4, 2008, Certain Questions of Mutual Assistance in Criminal Matters (Djib. v. Fr.), Press Release no.2008/2 (June 4, 2008), at 1. Int'l L. Comm'n, Draft articles on Responsibility of States for Internationally Wrongful Acts with Commentaries, Rep. of the Int'l L. Comm'n (2001), reprinted in [2001] 2 Y.B. Int'l L. Comm'n, U.N.Doc. A/56/10 \& Corr.1, at 55 and 117.

173 In in the Application of the Interim Accord of 13 September 1995 the Court did not consider Macedonia's contention that draft articles on countermeasures reflected customary international law. Application of the Interim Accord of 13 September 1995 (Maced. v. Greece), Judgment, 2011 I.C.J. 644, 99121, 164 (Dec. 5). The Court did not consider to be called upon to decide whether countermeasures form part of customary international law. Press Release, I.C.J., Speech by H.E. Judge Peter Tomka, President of the International Court of Justice, at the Sixty-fourth Session of the International Law Commission (July 24, 2012). In the Pulp Mills on the River Uruguay Case, the Court did not rely on art.12 of the Convention on the Law of the Non-Navigational Uses of International Watercourses, despite the Uruguay's counsel reliance to the convention in the pleadings. Convention on the Law of the Non-Navigational Uses of International Watercourses, May 21, 1997, U.N. Doc. 
guay invoked the United Nations Convention on the Law of Non-Navigational Uses of International Watercourses, drafted by the ILC, and ILC draft art.7 on the Prevention of transboundary harm from hazardous activities, but the Court did not mention either of them in its decision. The Court not only omitted any reference to the ILC's draft articles on Prevention of transboundary harm from hazardous activities; it also said it hoped that this judgment would contribute to the ILC's (ironically already finished) work in this area. ${ }^{174}$

The Court also did not mention ILC's work in the Questions Relating to the Obligation to Prosecute or Extradite Case. ${ }^{175}$ Although it considered draft art.14, para.1 and 2, art.30, art.42, para.(b)(i) and art.48 of the draft articles on State responsibility, the Court did not refer to these provisions, although it considered them in its previous decisions.

In recent years, the Court has shown general reluctance to refer to the ILC's work. However, after a series of cases in which the Court did not refer to the ILC, the ICJ relied heavily on ILC's work in the recent Jurisdictional Immunities of the State Case, discontinuing a potentially emerging trend of disagreements between the two international bodies. ${ }^{176}$

A/51/869. The ICJ applied only those provisions consistent with the 1975 Statute valid between Uruguay and Argentina. Press Release, I.C.J., Speech by H.E. Judge Rosalyn Higgins, President of the International Court of Justice, at the 59th Session of the International Law Commission (July 10, 2007).

174 Provisional Summary Records of the 3062nd Meeting, [2010] Y.B. Int'l Law Comm'n, U.N.Doc. A/CN.4/3062. The Court had decided the case only after the ILC has already concluded it work in this area. Pulp Mills on the River Uruguay (Arg. v. Uru.), Judgment, 2010 I.C.J. 14, at 67, 205 (Apr. 20).

175 Press Release, I.C.J., Speech by H.E. Judge Peter Tomka, President of the International Court of Justice, at the Sixty-fourth Session of the International Law Commission (July 24, 2012) (noting the views reflected the content of art.48 on State responsibility; the ICJ adopted the view which is compatible with the ILC's position). See also Questions Relating to the Obligation to Prosecute or Extradite (Belg. v. Sen.), 2012 I.C.J. 422, g965-69 (July 20) (the Court omitting to mention draft art.48 on State responsibility, but referring to Barcelona Traction Case, 968); Pulp Mills on the River Uruguay Case (art. 42 and art. 43); Ahmadou Sadio Diallo (Guinea v. Dem.Rep.Congo), Compensation, 2012 I.C.J. 324 (June 19) (art.30); Jurisdictional Immunities of the State (Germ. v. It.: Greece intervening), Judgment, 2012 I.C.J. 99, 143 (Feb. 3) (art. 14). The Court decided to rely on its precedent in Barcelona Traction Case to address the issue of common interest. Press Release, I.C.J., Speech by H.E. Judge Peter Tomka, President of the International Court of Justice, at the Sixty-fourth Session of the International Law Commission (July 24, 2012). The Court in its Judgment also uses the term 'common interest' which is mentioned in the commentary of art.48, para.(a) of the draft articles on State responsibility. Int'l L. Comm'n, Draft articles on Responsibility of States for Internationally Wrongful Acts with Commentaries, Rep. of the Int'l L. Comm'n (2001), reprinted in [2001] 2 Y.B. Int'l L. Comm'n, U.N.Doc. A/56/10 \& Corr.1, at 126. The ILC draft articles that could be applied also refer to Barcelona Traction Case. Barcelona Traction Case is also cited in the Commentary to draft art.1 on State responsibility. Id., at 33 .

176 Both parties to the dispute relied on the ILC's work. Senegal referred to the drafts in its 
The Most Recent Expression of the International Law-Making Relationship: A New Period?

In Jurisdictional Immunities of the State Case-the most recent case analyzed in this paper-the Court considered the United Nations Convention on Jurisdictional Immunities of States and Their Property, and the draft art.13, 30, para. (a), 35 and 41 on State responsibility. ${ }^{177}$ The ICJ acknowledged the contribution of the ILC as the legislator of the Convention and noted the ILC was a 'useful' forum for gathering information on domestic legislation and State comments to the draft articles. ${ }^{178}$ In finding customary international law in the Jurisdictional Immunities of the State Case the Court primarily relied on State practice and domestic legislation, and confirmed that the ILC's work was helpful to its reasoning. ${ }^{179}$ Taking into consideration that the Court is not bound by the ILC draft

written and oral proceedings four times, and Belgium referred to the ILC sixteen times. Counter-Memorial of Senegal, Questions relating to the Obligation to Prosecute or Extradite (Belg. v. Sen.), Pleadings, 2011 I.C.J. (Aug. 23), available at http://www.icj-cij.org/ docket/files/144/16931.pdf.

177 The Convention was drafted by the ILC and adopted by States at the codification conference in 2004. It has not yet entered into force. United Nations Convention on Jurisdictional Immunities of States and Their Property, Dec.2, 2004, U.N. Doc. A/59/508. This case is also an interesting example of the weight the Court accords to the treaty not yet in force and how it considers the ILC's preparatory work in this respect. "The issue before the Court is confined to acts committed on the territory of the forum State by the armed forces of a foreign State, and other organs of State working in co-operation with those armed forces, in the course of conducting an armed conflict." Jurisdictional Immunities of the State (Germ. v. It.: Greece intervening), Judgment, 2012 I.C.J. 99, 9955, 65 (Feb. 3). The issue before the Court was whether Italy violated Germany's jurisdictional immunity by allowing claims before Italian civil courts pursuant to violations of international humanitarian law committed by the Germany during World War II. Provisional Summary Records of the 3062nd Meeting, [2010] Y.B. Int'l Law Comm'n, U.N.Doc. A/CN.4/3062.

178 Provisional Summary Records of the 3148th Meeting, [2012] Y.B Int'l L. Comm'n, U.N.Doc. A/CN.4/SR.3148. The convention informed ICJ's reasoning and played an important role in its judgment. ILC's work is useful due to the comments made by the governments on the draft articles or the draft convention. For example, the Court in Germany v Italy used the comments made by China in 1990 and by the United States in 2004. Jurisdictional Immunities of the State (Germ. v. It.: Greece intervening), Judgment, 2012 I.C.J. 99, 64 (Feb. 3). "The almost complete absence of contrary jurisprudence is also significant, as is the absence of any statements by States in connection with the work of the International Law Commission regarding State immunity." Id., 977 . This is also one of the reasons why ILC's work is useful. It also encompasses the ILC work. Press Release, I.C.J., Speech by H.E. Judge Peter Tomka, President of the International Court of Justice, at the Sixty-fourth Session of the International Law Commission (July 24, 2012). Provisional Summary Records of the 3148th Meeting, [2012] Y.B Int'l L. Comm'n, U.N.Doc. A/CN.4/SR.3148.

179 Jurisdictional Immunities of the State (Germ. v. It.: Greece intervening), Judgment, 2012 I.C.J. 99, 962, 70, 72 (Feb. 3). Both Germany and Italy are not parties to the convention, which is not in force yet, and the Court could apply only the provisions which were of a customary nature. Both parties to the dispute claimed some provisions of the Convention to be customary international law. Italy claimed art.12 of the Convention is customary international law, while Germany claimed art.19 is customary international law. Id., 
articles nor its Commentary, ICJ's approach to ILC's work shows that the Court prefers to rely on its own determinations of what the applicable international law is on the matter, rather than on ILC's work.

\section{How Can the Relationship Between the International Court of Justi- ce and the International Law Commission be Improved: Some Ideas for the Future of International Law-Making}

Scholars-former frontrunners in developing international law-passed their torch of the international law-making to the international judicial system. ${ }^{180}$ The ICJ, while exercising its judicial functions, also expands and influences the formation of international law by (often unpredictably) incorporating internationally non-binding ILC draft articles into customary international law. The continuing increase of ICJ's reliance on ILC's work may be a consequence of the expansion of international law. The recent apparent reluctance of the ICJ to rely on ILC's work is therefore only temporary and of a limited scope. ${ }^{181}$

States are not actively engaging in international law-making and do not adopt the ILC draft articles into treaties. States have been reluctant to adopt the ILC's work as an internationally-binding instrument for more than a decade, ${ }^{182}$ marking a difference between the ILC's current silence and the past 'golden age' success. ${ }^{183}$ The ILC is partially to blame for States' passiveness in not adopting the

9115. "It follows that the Court must determine, in accordance with Article 38(1)(b) of its Statute, the existence of "international custom, as evidence of a general practice accepted as law" conferring immunity on States and, if so, what is the scope and extent of that immunity on the States..." Id., 955. This is an opposite situations as in the case of the North Sea Continental Shelf Case, when the court does not mention the disagreement, in order to confirm the customary status of the rule - it wants this status. In finding rules on customary international law, the Court looked primarily at State practice and opinio juris, but also acknowledged the importance of multilateral conventions in deriving rules of customary international law, including the Convention on Jurisdictional Immunities.

180 The influence of scholars in creating international law has diminished. Oppenheim, supra note 2, at 4, 5, 30 and 41; see also Schwebel, supra note 3, at 407. The current role of the ICJ in international law is resembling more common-law courts, unlike the PCIJ's resemblance to civil courts. Judicial law-making has become more acceptable. Kaczotowska, supra note 11, at 15 .

$181 \mathrm{Abi}$-Saab, supra note 2, at 927 (claiming the development of customary international law is the most visible expression of the expansion of international law); Rao, supra note 4, at 930 and 956 (claiming international tribunals expand and are an indicator of the expansion of international law, but the courts rather than fragment, unify international law contribute to the unity rather than to fragmentation); Guillaume, supra note 3, at 861-862 (claiming the proliferation of international courts jeopardizes the unity of international law). See also Pellet, supra note 17, at 22; and Alain Pellet, The Anatomy of Courts and Tribunals, 7 L. \& Practice of Int'l Ct. \& Trib. 27, 287 (2008).

182 States are currently not codifying ILC's work. The last two codification conferences were organized by the General Assembly in 1997 and 2004, respectively.

183 Jennings, supra note 2, at 346; see also Speech by Mrs. Edwige Belliard, Report of the International Law Commission on the work of its sixtieth session, General Observations (Oct. 29, 2008). 
ILC's work - the ILC's final products in the form of 'conclusions' or 'guidelines' effectively preclude States from incorporating the ILC's work into as a treaty. ${ }^{184}$

If the ILC methods established in 1949 were successful in past, they are no longer yielding the appropriate results today in the codification and development of the 'new' international law. ILC's Special Rapporteurs should follow specific standards established before researching a particular field of international law. ${ }^{185}$ ILC draft articles and conclusions are actively drafted only by a handful of ILC members who are willing to participate in the Drafting Committee's discussions. More transparency in the drafting process would not only incentivize States to adopt the ILC's draft articles, but could also help the Court identify evidence the ILC relied on in drafting the particular draft article. Mutual trust and transparency in the ICJ-ILC relationship also will lead to more coherence and predictability in identifying new norms of international law and developing some other areas of law. ${ }^{186}$

Both the ICJ and the ILC should survey the whole field of State practice independently and describe transparently their findings for the benefit of the international community as a whole. ${ }^{187}$ The ILC should become a depositary of information on State practice on a specific topic that the Court, scholars and international organizations can rely on. ${ }^{188}$ Every ILC member should be able to contribute to

184 By adopting guidelines and conclusions, ILC's work can be turned into international (binding) law only by the ICJ or State practice together with opinio juris. See Aegean Sea Continental Shelf Case (Greece v. Turk.), Judgment, 1978 I.C.J. 3, 42 (Dec. 19). See also Owada, The International Law Commission and the Process of Law-Formation, Making Better international Law: The International Law Commission at 50, Proceedings of the United Nations Colloquium on Progressive Development and Codification of International Law, United Nations Publication (1998), at 176-177. See also Danilenko, supra note 25, at 57 (noting a decline in the importance of the form in the treaty-making). Cf. Kolosov, Overview of the International Law-Making Process and the Role of the International Law Commission (Presentation), Making Better international Law: The International Law Commission at 50, Proceedings of the United Nations Colloquium on Progressive Development and Codification of International Law, United Nations Publication (1998), at 202.

185 There are currently no standards applicable to the work of the Special Rapporteurs, with the exception of the 50-page limit on the length of their reports.

186 Maritime Delimitation in the Area between Greenland and Jan Mayen (Den. v. Nor.), Judgment, 1993 ICJ REP 38, 87 (June 14) (separate opinion of Judge Ranjeva).

187 The ILC maintains a relationship with regional legislative bodies; in addition, the ILC is consulting non-governmental organizations, scholars and researchers. Rachmaran, supra note 14, at 202; Christine Chinkin, Enhancing the International Law Commission's Relationships with Other Law-Making Bodies and Relevant Academic and Professional Institutions (Presentation), Making Better international Law: The International Law Commission at 50, Proceedings of the United Nations Colloquium on Progressive Development and Codification of International Law 338 (U.N. Publication, 1998), at 135, 334-340. Cooperation of the ILC with other institutions enhanced the transparency of the ILC work. See also ILC Statute, art. 16, para (e), art.26, para.1.

188 Even though draft articles are considered by the Drafting Committee and the ILC plenary, Special Rapporteur's initial input has a significant influence on the overall work of the ILC 
the research on State practice and the relevant literature in their domestic jurisdiction. More Special Rapporteurs on a specific topic are needed for determining State practice of the whole international community. ${ }^{189}$ Although currently passive, the States should also not be left out of the international law-making process-the Court and the Commission should be clearer on what basis they determine that a rule forms part of customary international law.

The international law-making relationship between the ICJ and the ILC should be recognized by the General Assembly and noted in an international document that confirms their mutual influence. ${ }^{190}$ The ILC might consider sending its Chairman and the Special Rapporteurs on an annual visit to the ICJ for consultations to maintain a more 'uniform' vision of international law. ${ }^{191}$

The ILC needs to adopt rules regarding its working methods. Additionally, the ILC urgently needs new 'good' topics on uncodified areas of international law. The fourth Survey of International Law that the United Nations Codification Division is preparing should help the ILC perform its important task. ${ }^{192}$

on the topic. Jurisdictional Immunities of the State (Germ. v. It.: Greece intervening), Judgment, 2012 I.C.J. 99, 11 (Feb. 3) (dissenting opinion of Judge ad hoc Gaja).

189 Participation of all the members of the ILC in the Drafting Committee should be made compulsory and it should not be discouraged for reasons of expediency. The ILC should also stimulate its members for a more active participation and meaningful contribution; and discontinue the practice of the in-advance-prepared speeches that have an adverse impact on the creativity and searching for an intellectual compromise. Also, having more Special Rapporteurs from developing countries might contribute to the wider acceptance of the draft articles in the international community. The vast majority of former Special Rapportuers were either from Western Europe or United States. See also Pellet, supra note 17 , at 20 (noting the government officials-members of the ILC mainly come from the developing countries).

190 ICJ decisions are evidence of international law (Art. 24 ILC Statute). Art. 25 and art. 26 ILC Statute confer a legal basis for ICJ-ILC cooperation in future. See also Shahabuddeen, supra note 14, at 71 (noting the inconsistency between art.24 ILC Statute and art.38 ICJ Statute, where the ICJ judgments are not considered to be an evidence of customary international law). See also Special Rapporteur on the Law of Treaties, Int'l L.Comm'n, U.N.Doc. A/CN.4/23 (Apr.14, 1950) (by James Leslie Brierly), reprinted in [1950] 2 Y.B. Int'l L. Comm'n, U.N.Doc. A/1316 and Special Rapporteur on Formation and Evidence in Customary International Law, First report on Formation and evidence of customary international law, Int'l L. Comm'n, U.N. Doc. A/CN.4/663 (May 17, 2013) (by Sir Michael Wood).

191 At the visits to the ILC, the President of the Court reports on its current work and sometimes (implicitly) suggests points to areas of international law the ILC could consider. The speech of the ICJ President is followed by an informal debate.

192 Pellet, supra note 17, at 21-22. The ILC should also look at what areas of international law are still uncodified and undeveloped. E.g. Barcelona Traction, Light and Power Company, Limited, (Belg. v. Spain) (New Application: 1962), Judgment, 1970 I.C.J. 3 (Feb. 5) (in relation to international commercial law); Jurisdictional Immunities of the State (Germ. v. It.: Greece intervening), Judgment, 2012 I.C.J. 99, g953-54 (Feb. 3) (dissenting opinion of Judge Trinidade) (in relation to threshold of the gravity of the breaches of human rights and of international humanitarian law); Maritime Delimitation in the Black Sea (Rom. v. Ukr.), Judgment, 2009 I.C.J. 61 (Feb. 3) (in relation to historic waters, including

\section{(c) Palacký University Olomouc, Czech Republic, 2015. ISSN 1213-8770 (print), ISSN: 2464-6601 (online).}


Will modifying ILC's working methods be enough to revive ILC's past reputation? Despite the uncertain future of the (now) ILC draft conclusions, the personal link between the ICJ and the ILC continues to link the international bodies, as the ILC members continue to be elected as ICJ Judges. ${ }^{193}$ However, in order for this international law-making relationship to bear fruit, the ILC should set standards and guidelines for its work in the future. A more structured ILC research and drafting process, and more transparent working methods, may encourage a return to a greater reliance of States (and the Court) on ILC's work.

The relationship between the ICL and ILC establishes a platform for new and fresh ideas for the future of international law. International law has been with us for a long time, but the constellation and its functioning is still waiting to be fully discovered. In acknowledging the Court's increasingly important role in international law-making, ${ }^{194}$ and in further elaborating Professor Georges AbiSaab's idea of the 'universe of international law', the rules of international law become clearer when identified as part of the customary international law by the Court. Although the star might have existed long before the ICJ found it, the Court's discovery confirms its position in the constellation of international law.

historic bays); Continental Shelf (Tunis./Libya), Judgment, 1982 I.C.J. 18 (Feb. 24).

193 See Schwebel, supra note 7, at 67 (hinting on potential dissatisfaction with the quality of the draft articles and with the overall functioning of the Commission).

194 " $[\mathrm{T}]$ he court will continue to play this role in the future. International law has been developing at an ever faster pace; ... the international law-making process has gained an impressive and often underestimated momentum." Schwebel, supra note 3, at 415. 